\title{
Intestinal Gluconeogenesis Regulates Brown and White Adipose Tissues Functions in mice
}

\author{
Justine Vily-Petit $^{\text {a,b,c }}$, Maud Soty-Roca ${ }^{\text {a,b,c }}$, Marine Silva ${ }^{\text {a,b,c }}$, Manon Micoud ${ }^{\text {a,b,c }}$, Clara \\ Bron $^{\text {a,b,c }}$, Margaux Raffin ${ }^{\mathrm{a}, \mathrm{b}, \mathrm{c}}$, Daniel Beiroa ${ }^{\mathrm{d}, \mathrm{e}}$, Rubén Nogueiras ${ }^{\mathrm{d}, \mathrm{e}}$, Damien Roussel ${ }^{\mathrm{b}, \mathrm{c}, \mathrm{f}}$, \\ Amandine Gautier-Stein ${ }^{\text {a,b,c }}$, Fabienne Rajas ${ }^{\text {a,b,c }}$, Daniela Cota $^{\mathrm{g}}$, Gilles Mithieux ${ }^{\mathrm{a}, \mathrm{b}, \mathrm{c}}$

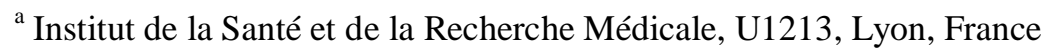 \\ ${ }^{\mathrm{b}}$ Université Claude Bernard Lyon1, Villeurbanne, France \\ ${ }^{\mathrm{c}}$ Université de Lyon, Lyon, France \\ ${ }^{\mathrm{d}}$ Department of Physiology, School of Medicine-CIMUS, University of Santiago de Compostela- \\ Instituto de Investigación Sanitaria, Santiago de Compostela, A Coruña, Spain \\ ${ }^{\text {e }}$ CIBER Fisiopatología de la Obesidad y Nutrición (CIBERobn), Santiago de Compostela, Spain \\ ${ }^{\mathrm{f}}$ Centre National de la Recherche Scientifique, UMR 5023 - LEHNA, Villeurbanne, France \\ ${ }^{g}$ Université Bordeaux, INSERM, Neurocentre Magendie, U1215F-3300, Bordeaux, France.
}

Address for correspondence:

Gilles Mithieux

Inserm 1213

Université Lyon I Laennec

7-11, rue Guillaume Paradin

69372 Lyon cedex 8

France

Lead contact: Gilles Mithieux (gilles.mithieux@inserm.fr)

Tel: + 33478778788

Word count : 4990

Figures count: 7 


\section{ABBREVIATIONS:}

AdipoQ: Adiponectin gene

ADP: Adenosine diphosphate

Adr $\beta 3$ : $\beta 3$-adrenergic receptor

BAT: Brown adipose tissue

CoxIV: Cytochrome c oxidase subunit 4

eWAT: Epididymal white adipose tissue

FADH2: Dihydroflavine-adenine dinucleotide

FCCP: p-trifluoromethoxy-carbonyl-cyanide-phenyl hydrazone

G6Pase: Glucose-6-phosphatase

G6PC: Catalytic subunit of Glucose-6-phosphatase

HF-HS: Hgh fat-high sucrose

HMW: high molecular weight form of adiponectin

Hsl: Hormone sensitive lipase

IGN: Intestinal gluconeogenesis

MRI: Magnetic resonance imaging

6-OHDA: 6-hydroxydopamine

Ppara: Peroxisome proliferator-activated receptor $\alpha$

Ppargc1a: Peroxisome Proliferator-Activated Receptor Gamma Coactivator 1- $\alpha$

PRDM16: PR domain containing 16

PVDF: Polyvinylidene fluoride

scWAT: Subcutaneous white adipose tissue

SDS: Sodium dodecyl sulfate

SEM: Standard error of the mean

SGLT3: Sodium-glucose co-transporter 3

SNS: Sympathetic nervous system

TH: Tyrosine hydroxylase

TNFa: Tumor necrosis factor $\alpha$

UCP1: Uncoupling Protein 1

WAT: White adipose tissue

WT: Wild-type 


\begin{abstract}
Objective: Intestinal gluconeogenesis, via the initiation of a gut-brain nervous circuit, accounts for the metabolic benefits linked to dietary proteins or fermentable fibre in rodents and has been positively correlated with the rapid amelioration of body weight after gastric bypass surgery in obese humans. In particular, the activation of intestinal gluconeogenesis moderates the development of hepatic steatosis accompanying obesity. In this study, we investigated the specific effects of intestinal gluconeogenesis on adipose tissue metabolism, independently of its induction by nutritional manipulation.
\end{abstract}

Methods: We used two transgenic mouse models of suppression or overexpression of G6PC, the catalytic subunit of glucose- 6 phosphatase, the key enzyme of endogenous glucose production, specifically in the intestine.

Results: Under a hypercaloric diet, mice with a genetic overexpression of intestinal gluconeogenesis showed a lower adiposity and higher thermogenic capacities than wild-type mice, featuring marked browning of white adipose tissue and prevention of the whitening of brown adipose tissue. Suppression of sympathetic nervous signalling in brown adipose tissue impairs the activation of thermogenesis. Conversely, mice with genetic suppression of intestinal gluconeogenesis exhibit an increase in adiposity under standard diet, associated with a decreased expression of markers of thermogenesis in both the brown and white adipose tissues.

Conclusion: Intestinal gluconeogenesis is sufficient in itself to activate the sympathetic nervous system and prevent the expansion and the metabolic alterations of brown and white adipose tissues metabolism under high calorie diet, thus preventing the development of obesity. These data increase knowledge of the mechanisms of weight reduction in gastric bypass surgery and pave the way of new approaches to prevent or cure obesity.

KEYWORDS: Adipose tissue, Gut-brain neural communication, Intestinal gluconeogenesis, Obesity, Thermogenesis. 


\section{INTRODUCTION}

The world is faced with an exponential increase in the prevalence of obesity. Unfortunately, the development of type 2 diabetes, which often accompanies the development of obesity, poses serious health problems, as retinopathy, nephropathy, neuropathy, cardiovascular diseases and various cancer types [1].

Adipose tissue, through its functions of energy storage and secretion of numerous hormones (the adipokines), is a crucial organ in energy balance. In mammals, the white adipose tissue (WAT) is mainly dedicated to lipid storage while the brown adipose tissue (BAT) is specialized in heat production. Both BAT and WAT can respond quickly to nutrient excess through adipocyte hypertrophy and hyperplasia. Adipose tissue remodeling is accelerated during the development of obesity, which involves metabolic alterations such as deregulation of fatty acid fluxes and dyslipidemia, mitochondrial dysfunctions and changes in adipokine synthesis. This leads to insulin resistance, chronic inflammation, fibrosis and even cell death [2]. In the early stages of obesity development, the WAT is a preferential storage site for excessive circulating lipids and is the first to undergo deleterious changes. However, the BAT is also recruited for lipid storage, and gradually loses its thermogenic capacity. This defect in turn contributes to the appearance of type- 2 diabetes and its associated complications [3]. What is more, compelling data strongly suggest that deregulated adipose tissue metabolism, via inflammation, could be an initiating factor in the development of type-2 diabetes [4].

In this context, it is noteworthy that intestinal gluconeogenesis (IGN) positively interferes with the control of glucose and energy homeostasis to exert anti-diabetic and antiobesity effects. More specifically, glucose released in the portal vein is sensed by a glucose 
receptor present in the gastrointestinal neural system (sodium-glucose co-transporter-3, SGLT3), which initiates a nervous signal to the hypothalamic nuclei regulating energy homeostasis [5-7]. The metabolic benefits previously observed in response to various nutritional manipulations in mice such as upon protein- or fibre-enriched diets, were strongly suggested to depend on the induction of IGN [8-11]. Moreover, IGN has been positively correlated with the rapid ameliorations in energy homeostasis after gastric bypass surgery, both in mice and in obese humans [12-14]. Thus, IGN participates to the prevention of body weight gain, the reduction in fat mass expansion and the improvement in glycaemic control under high calorie diet $[7,8,14,15]$. Using a mouse model of constitutive overexpression of glucose-6-phosphatase (G6Pase) in the intestine, we recently reported that the induction of IGN per se prevents hepatic steatosis under high calorie diet [16]. However, it remained to know whether there is a beneficial effect of IGN on adipose tissue physiology and the underlying mechanisms.

In this work, we deciphered the mechanisms evoked by IGN in the regulation of both WAT and BAT function. We studied: $\mathbf{1 /}$ whether the genetic induction of IGN could protect adipose tissue metabolism in a deleterious nutritional context (high fat-high sucrose (HF-HS) diet); 2/ whether the lack of IGN could be sufficient to lead to alterations in adipose metabolism in the context of a standard (starch-based) diet. We report that IGN, via the recruitment of the local sympathetic system, regulates key functions of adipose tissue metabolism.

\section{METHODS}

\subsection{Animals, diets and ethical statement}

We used two transgenic mouse models of suppression (I.G6pc ${ }^{-/-}$mice [11]) or overexpression (I.G6pc $^{\text {overexp }}$ mice [16]) of IGN by targeting G6pcl, the catalytic subunit of G6Pase that is 
the last enzyme operating before glucose release. Wild-type C57B16/J (WT, Charles River Laboratories, France) mice were used as control mice. All the mice were housed in the animal facility of Lyon 1 University (“Animalerie Lyon Est Conventionnelle and Specific Pathogen Free") under controlled temperature $\left(22^{\circ} \mathrm{C}\right)$ conditions, with a 12-h light/dark cycle, and ad libitum access to water and food. I.G6 $\mathrm{pc}^{-/-}$mice received standard chow diet and I.G6pc $\mathrm{covexp}^{\text {ove }}$ mice received HF-HS (5-months) or standard chow diet [16]. This study was conducted in males aged of 13 weeks (standard diet) or 8-months (HF-HS diet).

All procedures were performed in accordance with the principles and guidelines established by the European Convention for the protection of Laboratory Animals. The regional animal care committee (CEEA-55, University Lyon I, France) approved all the experiments herein.

\subsection{Histological and immunostaining analysis}

For histological analyses of adipose tissues, formalin-fixed and paraffin-embedded tissues were cut in $4 \mu \mathrm{m}$ thick sections and stained with hematoxylin and eosin staining, Masson's Trichrome staining, or immunostaining. For immunostaining, slices were incubated overnight at $4^{\circ} \mathrm{C}$ with primary antibodies produced in rabbits directed towards PRDM16 (PR domain containing 16) and UCP1 (Uncoupling Protein 1) (see supplementary material). The slices were then incubated for 30 minutes at room temperature with a secondary antibody coupled to Horseradish peroxidase and revealed using a 3,3'-diaminobenzidine solution. The nuclei were labelled with haematoxylin. The slices were observed using an inverted microscope (Nikon Eclipse TS2R).

For the slices of epididymal (eWAT) and subcutaneous (scWAT) white adipose tissue the number of adipocytes per $\mathrm{mm}^{2}$ were determined using Image J software ( $\mathrm{n}=6$; 4-15 pictures per mice). For the slices of BAT, the area occupied by the lipid droplets was determined using ImageJ software ( $\mathrm{n}=6 ; 4-15$ pictures per mice). 


\subsection{Electron Microscopy}

A piece $\left(1 \mathrm{~mm}^{3}\right)$ of eWAT and BAT was finely cut and added to a solution of glutaraldehyde 4\% and cacodylate buffer 0.2M (CIQLE platform, Université Lyon 1, SFR Santé Lyon-Est). Sections were observed with a transmission electron microscope JEOL-1400JEM (Tokyo, Japan) operating at $80 \mathrm{kV}$ equipped with a camera Orius-1000 gatan and Digital Micrograph. The number and the surface area of mitochondria were determined relatively to the cytoplasm area (excluding the lipid droplet) using ImageJ software ( $\mathrm{n}=4 ; 10$ pictures per mice).

\subsection{Magnetic resonance imaging analysis}

The measurement of body composition was using nuclear magnetic resonance imaging (MRI, Whole Body Composition Analyzer; EchoMRI; Houston, TX), as previously described $[17,18](\mathrm{n}=6-7)$.

\subsection{Temperature measurements}

Rectal and skin temperature surrounding BAT were measured and analyzed as previously described $[17,18]$. Briefly, body temperature was recorded with a rectal probe connected to a digital thermometer (BAT-12 Microprobe-Thermometer; Physitemp, Clifton, NJ). Skin temperature surrounding BAT was measured with an infrared camera (B335-Thermal Imaging Camera; FLIR; West Malling, Kent, UK) [20,21] and analyzed with FLIR-ToolsSoftware ( $\mathrm{n}=6-7 ; 2$ pictures per mice).

\subsection{Chemical denervation of the sympathetic nervous system and cold exposure}

Chemical denervation of BAT sympathetic nerve endings was performed in I.G6pc ${ }^{\text {overexp }}$ and WT mice fed standard diet [19] under isoflurane anaesthesia and ketoprofen $(1 \mathrm{mg} / \mathrm{kg})$ analgesia. This technique using several injections of 6-hydroxydopamine (6-OHDA), a neurotoxin selective for sympathetic neurons, permits a specific denervation, while keeping 
the sensory fibres intact. The effects of sympathetic denervation were compared to those obtained after vehicle injection $(0.15 \mathrm{~mol} / \mathrm{L} \mathrm{NaCl}, 1 \%$ ascorbic acid).

Briefly, the two lobes of brown interscapular adipose tissue were exposed through a midline skin incision along the upper dorsal surface and gently separated from the skin with surgical forceps. Then, several injections of 6-OHDA (Sigma-Aldrich) were performed directly into each lobe of the interscapular BAT. For each lobe, $10 \mu \mathrm{L}(6-\mathrm{OHDA}-10 \mathrm{mg} / \mathrm{mL})$ was injected in several times using a Hamilton syringe. The skin incision was then closed with several surgical stitches.

After 10 days of post-operative recovery, I.G6pc ${ }^{\text {overexp }}$ and WT mice were fasted for 5 hours, then re-fed and exposed to a cold temperature of $6^{\circ} \mathrm{C}$ for 4-hours. Rectal temperature and food intake were measured.

\subsection{Measurement of mitochondria respiratory capacity}

Fresh sample of BAT was homogenized with Dounce in a solution $(250 \mathrm{mM}$ Sucrose, $1 \mathrm{mM}$ EGTA, 20mM Tris-base, 1\% BSA, pH 7.3). Mitochondrion-enriched homogenate was obtained by successive centrifugations $(2 \mathrm{x}(1000 \mathrm{~g} ; 10 \mathrm{~min}), 2 \mathrm{x}(10000 \mathrm{~g} ; 10 \mathrm{~min}))$. The determinations were performed at $37^{\circ} \mathrm{C}$ on $1 \mathrm{mg} / \mathrm{mL}$ of protein in $200 \mu \mathrm{L}$ of solution composed of $120 \mathrm{mM} \mathrm{KCl}, 5 \mathrm{mM}$ KH2PO4, 1mM EGTA, 2mM MgCl2, 3mM Hepes, 0.3\% BSA, pH 7.4. Oxygen consumption was measured in a glass cell fitted with a Clark oxygen electrode (Rank Brothers Ltd) following the addition of different substrates, inhibitor, and uncoupler of the oxidative phosphorylation: Pyruvate/Malate $(5 \mathrm{mM} / 2,5 \mathrm{mM})$, ADP (Adenosinediphosphate, $1 \mathrm{mM})$, Succinate $(5 \mathrm{mM})$, Oligomycin $(2,5 \mu \mathrm{g} / \mathrm{mL})$, p-trifluoromethoxycarbonyl-cyanide-phenyl hydrazone (FCCP; $5 \mu \mathrm{M})$.

\subsection{Gene expression analysis}


Pieces of $150 \mathrm{mg}$ of frozen eWAT or $20 \mathrm{mg}$ of frozen BAT were homogenized using FastPrep ${ }^{\circledR}$ in Trizol reagent and total RNAs were isolated according to the manufacturer protocol (Invitrogen Life Technologies). Reverse transcription was done on $1 \mu \mathrm{g}$ of mRNA using the Qiagen QuantiTect Reverse Transcription kit. Real-time qPCRs were performed using sequence-specific primers supplied by Eurogentec (see supplementary material) with SsoAdvancedTM Universal SYBR® Green Supermix in a CFX-ConnectTM Real-Time System (Biorad).

The expression of mRNAs was normalized to the L32 (for eWAT) and cyclophilin (for scWAT and BAT) expression. The expression of target mRNAs was calculated using the 2$\Delta \Delta \mathrm{Ct}$ method and expressed relatively to WT controls.

\subsection{Western blot analysis}

Cell extracts from eWAT were lysed in standard lysis buffer $(20 \mathrm{mM}$ Tris-HCl, $\mathrm{pH} 8,138 \mathrm{mM}$ $\mathrm{NaCl}, 1 \% \mathrm{NP} 40,2.7 \mathrm{mM} \mathrm{KCl}, 1 \mathrm{mM} \mathrm{MgCl}$, 5\%glycerol, 5mM EDTA, 1mM Na3VO4, 20mM NaF, $1 \mathrm{mM}$ DTT, $1 \%$ protease inhibitors), and homogenized using FastPrep®. Proteins were assayed in triplicate with Pierce ${ }^{\mathrm{TM}}$ BCA Protein Assay Kit (Thermo Fisher Scientific).

Denaturing conditions: Aliquots of $30 \mu \mathrm{g}$ of proteins, denatured in buffer (20\% glycerol, $10 \%$ $\beta$-mercaptoethanol, $10 \%$ SDS, $62.5 \mathrm{mM}$ Tris) were analysed from $4 \%$, 9\% or $12 \%$-SDS polyacrylamide gel electrophoresis and transferred to PVDF Immobilon membranes (Biorad). After 1h-saturation in TBS/0.2\% Tween/2\% milk (RT), the membranes were probed (overnight at $4{ }^{\circ} \mathrm{C}$ ) with rabbit or mouse antibodies diluted in TBS $/ 0.2 \%$ Tween $/ 2 \%$ milk, against different proteins of interest, which names, references and dilutions are specified in the supplemental methods. Then, membranes were rinsed three-times in TBS/0.2\% Tween for $10 \mathrm{~min}$ and incubated for $1 \mathrm{~h}$ with goat secondary anti-rabbit or anti-mouse IgG linked to 
peroxidase (dilution 1:5,000; Biorad) in TBS/0.2\% Tween/2\% milk. Membranes were rinsed again and exposed to ClarityTM Western ECL Substrate (Biorad). The intensity of the spots was determined by densitometry with ChemiDoc Software (Biorad) and analysed using the Image LabTM software (Biorad). Quantification of the $\alpha \beta$-tubulin, $\beta$-Actin or whole protein levels (using the stain free protocol provided by Biorad) was used for normalization. StainFree technology enabled fluorescent visualization of 1-D SDS PAGE gels and corresponding blots. The relative amount of total protein in each lane on the blot was calculated and used for quantitation normalization. Western blots were trimmed on the sides to show 3-4 representative samples of each experimental condition.

Non-denaturing conditions: To analyse the different conformations of adiponectin, aliquots of $30 \mu \mathrm{g}$ of protein were prepared in native Tris glycine sample buffer and analysed from NuPAGE 3-8\% Tris-Acetate polyacrylamide gel electrophoresis in a tris-glycine native running buffer (Thermo Fisher Scientific). After 2-hours of migration at $130 \mathrm{~V}$, proteins were transferred to PVDF Immobilon membranes (Biorad). After 1h-saturation in TBS/0.2\% Tween $/ 2 \%$ milk (RT), the membranes were probed (overnight at $4^{\circ} \mathrm{C}$ ) with rabbit antibodies diluted in TBS/0.2\% Tween/ $2 \%$ milk (see supplementary material). Then, membranes were rinsed three-times in TBS/ $0.2 \%$ Tween for $10 \mathrm{~min}$ and incubated for $1 \mathrm{~h}$ with goat secondary anti-rabbit IgG linked to peroxidase (dilution 1:5 000, Biorad) in TBS/0.2\% Tween/2\% milk. Membranes were rinsed again and exposed to ClarityTM Western ECL Substrate (Biorad). The intensity of the spots was determined by densitometry with ChemiDoc Software (Biorad) and analysed using the Image LabTM software (Biorad). The results were expressed as a ratio between the HMW and MMW forms of adiponectin (High molecular weight / Medium molecular weight).

\subsection{Statistical analysis}


All data are presented as mean \pm SEM (standard error of the mean). Two-group and multigroup comparisons were analysed using unpaired t test or ANOVA-2 followed by Bonferroni post-hoc test, respectively. Values were considered significant at $* \mathrm{p} \square<\square 0.05$; ** $\mathrm{p}<0.01$ and *** $p<0.001$. Statistical details and exact value of " $n$ " can be found in the figure legends. Statistical analyses were performed with GraphPad Prism 9 software.

\section{RESULTS}

\subsection{Intestinal gluconeogenesis prevents the development of fat mass in mice fed a} high fat-high sucrose diet

In agreement with our previous studies reporting the protective effect of IGN overexpression against the development of obesity, MRI data indicated that I.G6pc ${ }^{\text {overexp }}$ mice had a lower fat mass than WT mice fed a HF-HS diet (Fig. 1a). Consistently with this observation, hematoxylin-stained eWAT and scWAT sections showed an increased number of adipocytes per $\mathrm{mm}^{2}$ in I.G6pc ${ }^{\text {overexp }}$ mice compared to WT mice (Fig. 1b), highlighting adipocyte hypotrophy. Moreover, adipocytes in the BAT of I.G6pc ${ }^{\text {overexp }}$ contained smaller and greater number of lipid droplets than WT mice. This translates into a smaller lipid droplets area (Fig. 1b). In line with this reduction in lipid storage, the expression levels of Perilipin, which is the major lipid droplet coat protein in mature adipocytes was decreased in eWAT and BAT of I.G6pc ${ }^{\text {overexp }}$ mice as compared to WT mice (Fig. 1c).

\subsection{Intestinal gluconeogenesis promotes thermogenesis and prevents whitening processes in brown adipose tissue in mice fed a high fat-high sucrose diet}

During the development of obesity, all adipose depots are recruited for lipid storage. In BAT, increased lipid storage leads to its whitening, which refers to the conversion of 
brown adipocytes in white unilocular cells expressing genes encoding white adipocytespecific hormones, such as leptin [20,21]. In line with the protection from excessive lipid accumulation described above (Fig. 1), Leptin expression, a major marker of the whitening of the BAT, was decreased by about $60 \%$ in the BAT of I.G6pc ${ }^{\text {overexp }}$ mice compared to WT mice (Fig. 2a).

While thermogenesis is an essential component of energy expenditure, particularly in the control of energy homeostasis, the loss of BAT thermogenic capacities promotes body weight gain during obesity development $[4,22,23]$. Interestingly, I.G6pc ${ }^{\text {overexp }}$ mice showed a higher inter-scapular and rectal temperature compared to WT mice, suggesting an active thermogenesis taking place in the BAT (Fig. 2b). Moreover, we demonstrated by immunochemistry determinations that the amount of two major thermogenic proteins, UCP1 and PRDM16 was higher in the BAT of I.G6pc ${ }^{\text {overexp }}$ than in WT mice (Fig. 2c). In line with an increase in thermogenesis in the BAT of I.G6pc ${ }^{\text {overexp }}$ mice, electron microscopy analysis revealed that mitochondria were larger in these mice compared to WT mice, while the total number of mitochondria was not different (Fig. 2d-e-f). This modification in mitochondrial size could impact mitochondrial activity [24,25]. Accordingly, the mitochondrial respiratory

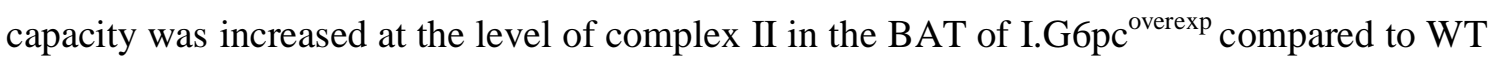
mice, with no change in the activity of complex I (Fig. 2g). In addition, the experiment using an uncoupling agent (FCCP) demonstrated that there was a trend to a global increase in the maximal mitochondrial respiratory capacity in the BAT of I.G6pc ${ }^{\text {overexp }}$ mice (Fig. 2g).

Therefore, the induction of IGN prevented the BAT whitening usually occurring under a high calorie diet, thus preserving the BAT thermogenic capacities helping in turn protect from body weight gain. 


\subsection{Intestinal gluconeogenesis promotes the browning of epididymal white adipose tissue in mice fed a high fat-high sucrose diet}

White adipose tissue can acquire thermogenic capacities under certain conditions, such as cold exposure, according to a process named "browning". The browning of WAT is often described as taking place primarily in scWAT during cold exposure [26]. However, analysis of scWAT of I.G6pc ${ }^{\text {overexp }}$ mice did not show significant change in the mRNA expression of Ucpl and Prdm16 (Fig. S1).

Differently, when analysis was carried out on the eWAT, we observed an increase in the expression levels $U c p 1, \operatorname{Prdm16}$ in I.G6pc ${ }^{\text {overexp }}$ mice (Fig. 3a). Interestingly, while the sympathetic nervous system (SNS) is the main regulator of the browning process, the expression level of $\beta 3$-adrenergic receptor (Adrß3) was increased in I.G6pc ${ }^{\text {overexp }}$ mice (Fig. 3a). Moreover, the expression of major genes involved in lipid oxidation, as CoxIV (Cytochrome c oxidase subunit 4), Ppara (Peroxisome proliferator-activated receptor alpha), and the critical regulator of thermogenesis Ppargcla (Peroxisome Proliferator-Activated Receptor Gamma Coactivator 1-Alpha), and in lipolysis, as Hsl (Hormone sensitive lipase) were increased in the eWAT of I.G6pc ${ }^{\text {overexp }}$, highlighting stimulation of adipocyte metabolism (Fig. 3b). However, there was no difference in the size or in the number of mitochondria in the eWAT from both experimental groups (Fig. 3d-e-f).

\subsection{Intestinal gluconeogenesis improves cold resistance by involving the sympathetic nerves}

The SNS is the main regulator of BAT thermogenesis [27,28]. Accordingly, increased thermogenesis in I.G6pc ${ }^{\text {overexp }}$ mice was associated with a higher protein expression of tyrosine hydroxylase $(\mathrm{TH})$, which is an enzyme essential for the synthesis of catecholamines. (Fig. 4a). 
To further investigate the effects of IGN in the regulation of adipose tissue thermogenesis, we studied the effects of its activation on cold resistance in a standard dietary context. More specifically, we investigated whether the increase in thermogenesis in I.G6pc ${ }^{\text {overexp }}$ mice (Figures 2-3 above) could confer on them a better resistance to cold even on a standard chow diet. In addition, we tested the involvement of the SNS in the transmission of the beneficial effects of IGN relating to the resistance to cold. For this purpose, we performed injections restricted to the BAT of a specific SNS neurotoxin, 6-OHDA. Ten-days after the surgery, WT and I.G6pc ${ }^{\text {overexp }}$ mice, subdivided into two groups - control (sham/vehicle treated) and denervated (6-OHDA treated) - were exposed to cold and their rectal temperature measured (Fig. 4b). While we observed the improvement of cold resistance in I.G6pc ${ }^{\text {overexp }}$-sham mice, these effects did not take place in the absence of sympathetic nerve fibres in the BAT in I.G6pc ${ }^{\text {overexp }}$ 6-OHDA treated mice (Fig. 4b). Thus, while IGN increases thermogenesis both in the BAT and eWAT, these data suggest a prominent role for BAT in maintaining body temperature during short cold exposure (4-hours; $\left.6^{\circ} \mathrm{C}\right)(\mathbf{F i g} . \mathbf{4 b})$. In addition, these results were not accompanied by a change in food intake, which excludes any interference of diet-induced thermogenesis with the effects (Fig. S2).

Therefore, while the activation of IGN increased thermogenesis, using a chemical SNS denervation approach, we clarified that the modulation of SNS is necessary to observe this modulation deriving from IGN activation.

\subsection{Intestinal gluconeogenesis modulates adipokine secretion in the context of high fat-high sucrose diet}

During the development of obesity, the WAT is a site of numerous deleterious changes, including the increase in the production and release of proinflammatory cytokines. The later can lead to the proliferation of the extra-cellular matrix, contributing to fibrosis 
development in adipose tissue [29,30]. Interestingly we observed that the eWAT of I.G6pc ${ }^{\text {overexp }}$ mice showed a decrease in the gene expression of the proinflammatory marker TNF $\alpha$ (Tumor necrosis factor alpha), without significant change in the expression of other proinflammatory adipokines (Fig. 5a). In addition, the observation of Masson trichromestained eWAT sections strongly suggested a prevention of fibrosis in I.G6pc ${ }^{\text {overexp }}$ mice (Fig. 5b)

In parallel, we observed an increase in the mRNA expression of adiponectin (AdipoQ) (Fig. 5c), an adipokine known to improve insulin sensitivity, lipid metabolism and inflammation [31]. Moreover, we measured an increase in the high molecular weight form (HMW) of adiponectin, which corresponds to the biologically active form exerting the majority of its beneficial metabolic effects [32] (Fig. 5d).

\subsection{Specific suppression of intestinal gluconeogenesis promotes lipid storage and alteration in adipokine secretion in mice fed a standard diet}

To get further insight in the mechanisms by which IGN modulates the metabolism of BAT and WAT, we used mice with specific deletion of IGN (I.G6pc ${ }^{-/-}$mice). At the opposite of what occurred in I.G6pc ${ }^{\text {overexp }}$ mice, the absence of this function promoted lipid storage in the WAT, illustrated by an increase in body weight (Fig. 6a) and in the weight of the eWAT and scWAT in I.G6pc ${ }^{-/-}$mice compared with WT mice (Fig. 6b-c). Hematoxylin-stained sections of adipose tissues revealed a hyperplasia of adipocytes in the eWAT and scWAT and an increased area occupied by lipid droplets in the BAT of I.G6 $\mathrm{pc}^{-/-}$mice, compared to WT mice (Fig. 6d).

In agreement with increased adiposity in I.G6pc ${ }^{-/-}$mice, Perilipin expression was increased in the eWAT, albeit not in the scWAT and BAT (Fig. 6e). Relating to thermogenic markers, the BAT of I.G6pc $\mathrm{pc}^{-/}$mice exhibited a decrease in the expression of Ucpl (Fig. 6f). 
It is noteworthy that, at the opposite of what took place in I.G6pc ${ }^{\text {overexp }}$ mice, IGN deficiency led to a decrease in the expression of genes involved in thermogenic capacities, such as Ppargcla, CoxIV and $\mathrm{Hsl}$ in the eWAT (Fig. 6g). In agreement, the expression level of the thermogenesis markers UCP1 and PRDM16 were also decreased in the eWAT of I.G6pc ${ }^{-/-}$mice (Fig. 6h). In addition, we showed a decrease in Adrb3 expression levels (Fig. 6g).

Interestingly, the absence of IGN was sufficient to increase the expression level of the pro-inflammatory markers $I l-1$ and $I l-6$, and the necrosis factor Tnfa in the eWAT (Fig. 7a-b). Furthermore, in mirror again of the situation in I.G6pc ${ }^{\text {overexp }}$ mice, IGN deficiency lead to a decrease in the expression level of AdipoQ and of the HMW conformation of Adiponectin. (Fig. 7c-d).

Altogether, these data highlight that the absence of IGN is sufficient to alter adipose tissue metabolism, even in young mice (13-weeks old) and in a standard feeding context.

\section{DISCUSSION}

The metabolic benefits conferred by the induction of IGN were previously observed upon various nutritional manipulations. Indeed, IGN is a causal link in the anti-obesity and anti-diabetic effects of dietary proteins and soluble fibres and of gastric bypass surgery $[7,8,10,11,13,14,33]$. In order to study the beneficial effects of IGN per se, independently of the nutritional context, we used mouse models of overexpression or suppression of IGN, by targeting G6PC, the catalytic subunit of G6Pase.

In agreement with a marked effect of prevention of obesity, the induction of IGN leads to a reduction of lipid storage in eWAT, scWAT and BAT. The expansion of adipose tissue 
during the development of obesity is associated with deregulation of fatty acid fluxes and can lead to hypoxia and adipocyte death, which promotes pro-inflammatory and insulin-resistant states (for review see [34]). The prevention of this expansion by IGN is therefore a key benefit in the context of metabolic diseases.

The BAT is the main player in non-shivering thermogenesis. In obese subjects, BAT undergoes profound deleterious changes. Especially, the activity of BAT decreases while adiposity increases $[35,36]$. Thus, BAT thermogenesis represents a therapeutic target in the treatment of obesity and the prevention of its associated complications $[37,38]$. In this context, we show here that I.G6pc ${ }^{\text {overexp }}$ mice exhibit an increase in heat production by the BAT associated with higher body temperature. Moreover, our data strongly suggest that the induction of IGN protects the BAT against the whitening process known to occur in deleterious nutritional contexts (such as high calorie diet) and to induce the loss of thermogenic capacities $[4,22,23]$.

The morphology of mitochondria is a key parameter for an optimal metabolic activity of BAT, especially for thermogenesis [25,37]. Accordingly, mitochondria in the BAT are more numerous and larger than their counterparts in the WAT [24]. Therefore, the increase in mitochondria size in the BAT of I.G6pc ${ }^{\text {overexp }}$ mice, associated with increased expression of UCP1 and PRDM16, could contribute to the induction of heat production. Moreover, the induction of UCP1-dependent thermogenesis by cold exposure requires an increase in the activity of complex II of the respiratory chain, essential for the oxidation of FADH2 (Dihydroflavine-adenine dinucleotide) generated from lipid oxidation, while an inhibition of complex II suppresses cold-induced thermogenesis [39]. Accordingly, the increase in complex II activity measured in the BAT of I.G6pc ${ }^{\text {overexp }}$ mice is in agreement both with the increased heat production by the interscapular region and with the associated mobilization of lipids for that. 
Both BAT thermogenesis and the process of browning in WAT, which corresponds to the appearance of beige adipocytes capable of producing heat, are controlled by the SNS $[37,38,40,41]$. In line with this, IGN induction led to an increase in the expression levels of thermogenic markers and $\beta 3$-adrenergic receptor in the eWAT. In addition, the protein expression level of tyrosine hydroxylase, an enzyme essential for the synthesis of catecholamines, was increased in the BAT of I.G6pc ${ }^{\text {overexp }}$ mice fed HF-HS diet. Interestingly, while this increased thermogenesis in both BAT and WAT likely contributes to both the better resistance to cold in I.G6pc ${ }^{\text {overexp }}$ mice, we clarify here the mechanisms evoked by the activation of the IGN in adipose tissues from a SNS chemical denervation approach. Indeed, this effect doesn't occur after the inactivation by 6-OHDA of BAT-sympathetic innervation. Thus, although the increased WAT browning can be beneficial in maintaining energy balance on HF-HS diet, the effect of IGN on BAT thermogenesis appears to be predominant compared with that in WAT regarding thermogenesis and cold resistance. Altogether, these data strongly suggest that IGN promotes the BAT thermogenesis and the browning of the WAT by involving a gut-brain-adipose tissue neural loop activating the sympathetic tone.

It is noteworthy that mice lacking IGN show a picture in mirror compared to I.G6pc ${ }^{\text {overexp }}$ mice, including an increase in the size of adipocytes and lipid droplets associated with a decrease in the expression levels of thermogenic markers in both the eWAT and BAT. These alterations could be linked to the development of dyslipidaemia observed in the absence of IGN [16]. Indeed, the decrease in adipose tissue thermogenesis could be responsible, at least in part, for the increase in plasma triglycerides observed in I.G6 $\mathrm{pc}^{-/-}$mice [16]. This excess may contribute to ectopic lipid accumulation in others tissues, particularly in the liver, thus contributing to worsen hepatic insulin resistance in I.G6 $\mathrm{pc}^{-/-}$mice [16]. Conversely, the activation of both the eWAT and BAT metabolism in I.G6pc ${ }^{\text {overexp }}$ mice could 
contribute to the prevention of hepatic lipid storage and the moderation of body weight gain on HF-HS diet [16].

Interestingly, the adipose tissue is also an important endocrine tissue implicated in the regulation of carbohydrate and energy homeostasis via the secretion of the so-called adipokines [42]. During the development of obesity, the secretion profile of these hormones is altered with a decrease in the beneficial adipokines, such as adiponectin, in favour of proinflammatory adipokines [42]. A decrease in circulating adiponectin levels in obese patients was proposed to have a crucial role in the pathogenesis of metabolic complications associated with obesity, especially hepatic steatosis $[43,44]$. It is noteworthy that I.G6pc ${ }^{\text {overexp }}$ mice show an increase in gene expression of adiponectin and of its HMW conformation that is the main biologically active form mediating its metabolic benefits, such as the improvement of hepatic insulin sensitivity or of lipid metabolism $[43,44]$. Thus, these changes in adiponectin metabolism may be involved in the protection against the development of hepatic steatosis and the observed delay in the onset of diabetes on high calorie diet in I.G6pc ${ }^{\text {overexp }}$ mice [16]. In contrast, I.G6 $\mathrm{pc}^{-/-}$mice exhibit a decrease in the HMW adiponectin form. These alterations could be partly involved in the development of the pre-diabetic state and increase in hepatic lipid content previously observed in I.G6 $\mathrm{pc}^{-/-}$mice, notably characterized by hepatic insulin resistance $[16,45]$.

It is noteworthy that several studies suggested functional differences in white adipose tissue depots depending on their anatomical location. While the mass of visceral adipose tissue is associated with peripheral insulin resistance, the preferential accumulation of lipids in the scWAT could be protective against metabolic complications [46,47]. Accordingly, the surgical removal of eWAT in rodents prevents the development of obesity, insulin resistance, dyslipidaemia and hepatic steatosis while increasing the storage in the scWAT, a process possibly linked to adipokines [47]. Thus, it seems particularly interesting on a physiological 
viewpoint that IGN increases browning in a visceral depot as the eWAT, since, in addition, this fat pad is generally suggested to be less susceptible to browning compared to the scWAT [48-50].

\section{CONCLUSION}

In conclusion, we here decipher the beneficial effects of IGN in the regulation of energy homeostasis. IGN positively controls fat storage, thermogenic capacities and the adipokine secretion profile through a gut-brain-adipose tissue neural circuit involving the sympathetic nerves. Moreover, this modulation may take place from the only activation of IGN, independently of any additional nutritional manipulation. Therefore, these data highlight that activating IGN constitutes a potential therapeutic target to prevent or correct obesity and its deleterious metabolic consequences, including the pathological expansion of adipose tissue and the thermogenesis decline. This could account at least in part for the weight loss processes occurring after gastric bypass surgery or upon fibre feeding in obese humans. Thus, these data may pave the way to novel approaches of prevention or treatment of metabolic diseases as obesity or type-2 diabetes. The search for molecules capable of activating the IGN and its beneficial metabolic effects is a major challenge for the coming years.

\section{ACKNOWLEDGMENTS}

We thank the members of Animalerie Lyon Est Conventionnelle et SPF (ALECS, Université Lyon 1, SFR Santé Lyon Est) for animal housing and care, and the members of the CIQLE platform (Université Lyon 1, SFR Santé Lyon Est) for histological and electron microscopy experiments (Université Lyon 1). 


\section{$\underline{\text { AUTHOR CONTRIBUTIONS }}$}

J.V-P. designed, conducted experiments, analysed the data and wrote the paper. M.S-R. designed, conducted experiments and analysed the data. M.S. M.M, C.B and M.R. were in charge of mouse breeding and animal experiments. D.B and R.N performed MRI and skin temperature surrounding BAT measurement and analysis. D.R performed the measurement and the analysis of mitochondria respiratory capacity. R.N, D.R, A.G-S, F.R and D.C critically edited the manuscript. G.M. supervised the studies and wrote the paper

\section{FUNDING STATEMENT}

This work was supported by research grants from the Institut National de la Santé et de la Recherche Médicale (INSERM), the Agence Nationale de la Recherche (ANR-17-CE140020-01), the Fondation pour la Recherche Médicale (Equipe FRM DEB20160334898) and the company Servier.

\section{CONFLICT OF INTEREST STATEMENT}

None of the authors has a conflict of interest to disclose relating to the work described in this paper.

\section{REFERENCES}

[1]. Segula D. Complications of obesity in adults: A short review of the literature. Malawi Med J. 2014 Mar;26(1):20-4.

[2]. Strissel KJ, Stancheva Z, Miyoshi H, Perfield JW, DeFuria J, Jick Z, et al. Adipocyte death, adipose tissue remodeling, and obesity complications. Diabetes. 2007 Dec;56(12):2910-8.

[3]. Kotzbeck P, Giordano A, Mondini E, Murano I, Severi I, Venema W, et al. Brown adipose tissue whitening leads to brown adipocyte death and adipose tissue inflammation. J Lipid Res. 2018 May;59(5):784-94.

[4]. Lee M-W, Lee M, Oh K-J, Adipose Tissue-Derived Signatures for Obesity and Type 2 Diabetes: Adipokines, Batokines and MicroRNAs. J Clin Med. 2019 Jun 14;8(6):854. 
[5]. Delaere F, Duchampt A, Mounien L, Seyer P, Duraffourd C, Zitoun C, et al. The role of sodium-coupled glucose co-transporter 3 in the satiety effect of portal glucose sensing. Mol Metab. 2013 Feb;2(1):47-53.

[6]. Delaere F, Akaoka H, De Vadder F, Duchampt A, Mithieux G. Portal glucose influences the sensory, cortical and reward systems in rats. Eur J Neurosci. 2013 Nov;38(10):347686.

[7]. Soty M, Gautier-Stein A, Rajas F, Mithieux G. Gut-Brain Glucose Signaling in Energy Homeostasis. Cell Metab. 2017 Jun 6;25(6):1231-42.

[8]. De Vadder F, Kovatcheva-Datchary P, Goncalves D, Vinera J, Zitoun C, Duchampt A, et al. Microbiota-Generated Metabolites Promote Metabolic Benefits via Gut-Brain Neural Circuits. Cell. 2014 Jan 16;156(1-2):84-96.

[9]. Duraffourd C, De Vadder F, Goncalves D, Delaere F, Penhoat A, Brusset B, et al. MuOpioid Receptors and Dietary Protein Stimulate a Gut-Brain Neural Circuitry Limiting Food Intake. Cell. 2012 Jul 20;150(2):377-88.

[10]. Mithieux G, Misery P, Magnan C, Pillot B, Gautier-Stein A, Bernard C, et al. Portal sensing of intestinal gluconeogenesis is a mechanistic link in the diminution of food intake induced by diet protein. Cell Metab. 2005 Nov;2(5):321-9.

[11]. Penhoat A, Mutel E, Amigo-Correig M, Pillot B, Stefanutti A, Rajas F, et al. Proteininduced satiety is abolished in the absence of intestinal gluconeogenesis. Physiol Behav. 2011 Nov 30;105(1):89-93.

[12]. Gutierrez-Repiso C, Garcia-Serrano S, Moreno-Ruiz FJ, Alcain-Martinez G, RodriguezPacheco F, Garcia-Fuentes E. Jejunal gluconeogenesis associated with insulin resistance level and its evolution after Roux-en-Y gastric bypass. Surg Obes Relat Dis Off J Am Soc Bariatr Surg. 2017 Apr;13(4):623-30.

[13]. Mithieux G. Comment about intestinal gluconeogenesis after gastric bypass in human in relation with the paper by Hayes et al., Obes. Surg. 2011. Obes Surg. 2012 Dec;22(12):1920-2; author reply 1923-1924.

[14]. Troy S, Soty M, Ribeiro L, Laval L, Migrenne S, Fioramonti X, et al. Intestinal gluconeogenesis is a key factor for early metabolic changes after gastric bypass but not after gastric lap-band in mice. Cell Metab. 2008 Sep;8(3):201-11.

[15]. Sun D, Wang K, Yan Z, Zhang G, Liu S, Liu F, et al. Duodenal-jejunal bypass surgery up-regulates the expression of the hepatic insulin signaling proteins and the key regulatory enzymes of intestinal gluconeogenesis in diabetic Goto-Kakizaki rats. Obes Surg. 2013 Nov;23(11):1734-42.

[16]. Vily-Petit J, Soty-Roca M, Silva M, Raffin M, Gautier-Stein A, Rajas F, et al. Intestinal gluconeogenesis prevents obesity-linked liver steatosis and non-alcoholic fatty liver disease. Gut. 2020 Dec;69(12):2193-2202.

[17]. Martínez de Morentin PB, Whittle AJ, Fernø J, Nogueiras R, Diéguez C, Vidal-Puig A, et al. Nicotine Induces Negative Energy Balance Through Hypothalamic AMPActivated Protein Kinase. Diabetes. 2012 Apr;61(4):807-17. 
[18]. Martínez de Morentin PB, González-García I, Martins L, Lage R, Fernández-Mallo D, Martínez-Sánchez N, et al. Estradiol regulates brown adipose tissue thermogenesis via hypothalamic AMPK. Cell Metab. 2014 Jul 1;20(1):41-53.

[19]. Vaughan CH, Zarebidaki E, Ehlen JC, Bartness TJ. Analysis and measurement of the sympathetic and sensory innervation of white and brown adipose tissue. Methods Enzymol. 2014;537:199-225.

[20]. Cancello R, Zingaretti MC, Sarzani R, Ricquier D, Cinti S. Leptin and UCP1 genes are reciprocally regulated in brown adipose tissue. Endocrinology. 1998 Nov;139(11):474750.

[21]. Cinti S, Frederich RC, Zingaretti MC, De Matteis R, Flier JS, Lowell BB. Immunohistochemical localization of leptin and uncoupling protein in white and brown adipose tissue. Endocrinology. 1997 Feb;138(2):797-804.

[22]. Cinti S. Transdifferentiation properties of adipocytes in the adipose organ. Am J Physiol Endocrinol Metab. 2009 Nov;297(5):E977-986.

[23]. Giordano A, Smorlesi A, Frontini A, Barbatelli G, Cinti S. White, brown and pink adipocytes: the extraordinary plasticity of the adipose organ. Eur J Endocrinol. 2014 May;170(5):R159-171.

[24]. Cedikova M, Kripnerová M, Dvorakova J, Pitule P, Grundmanova M, Babuska V, et al. Mitochondria in White, Brown, and Beige Adipocytes. Stem Cells Int. 2016/03/17 ed. 2016;2016:6067349-6067349.

[25]. Desautels M, Himms-Hagen J. Parallel regression of cold-induced changes in ultrastructure, composition, and properties of brown adipose tissue mitochondria during recovery of rats from acclimation to cold. Can J Biochem. 1980 Oct;58(10):1057-68.

[26]. Kalinovich AV, de Jong JMA, Cannon B, Nedergaard J. UCP1 in adipose tissues: two steps to full browning. Biochimie. 2017 Mar 1;134:127-37.

[27]. Morrison SF, Madden CJ, Tupone D. Central Neural Regulation of Brown Adipose Tissue Thermogenesis and Energy Expenditure. Cell Metab. 2014 May 6;19(5):741-56.

[28]. Bachman ES, Dhillon H, Zhang C-Y, Cinti S, Bianco A, Kobilka B, et al. betaAR signaling required for diet-induced thermogenesis and obesity resistance. Science. 2002 Aug 2;297(5582):843-5.

[29]. Khan T, Muise ES, Iyengar P, Wang ZV, Chandalia M, Abate N, et al. Metabolic Dysregulation and Adipose Tissue Fibrosis: Role of Collagen VI. Mol Cell Biol. 2009 Mar;29(6):1575-91.

[30]. O'Hara A, Lim F-L, Mazzatti DJ, Trayhurn P. Microarray analysis identifies matrix metalloproteinases (MMPs) as key genes whose expression is up-regulated in human adipocytes by macrophage-conditioned medium. Pflugers Arch. 2009 Oct;458(6):110314.

[31]. Esmaili S, Hemmati M, Karamian M. Physiological role of adiponectin in different tissues: a review. Arch Physiol Biochem. 2020 Feb;126(1):67-73. 
[32]. Wang ZV, Scherer PE. Adiponectin, the past two decades. J Mol Cell Biol. 2016 Apr $1 ; 8(2): 93-100$.

[33]. De Vadder F, Kovatcheva-Datchary P, Zitoun C, Duchampt A, Bäckhed F, Mithieux G. Microbiota-Produced Succinate Improves Glucose Homeostasis via Intestinal Gluconeogenesis. Cell Metab. 2016 12;24(1):151-7.

[34]. Sun K, Kusminski CM, Scherer PE. Adipose tissue remodeling and obesity. J Clin Invest. 2011 Jun 1;121(6):2094-101.

[35]. Saito M, Okamatsu-Ogura Y, Matsushita M, Watanabe K, Yoneshiro T, Nio-Kobayashi $\mathrm{J}$, et al. High Incidence of Metabolically Active Brown Adipose Tissue in Healthy Adult Humans. Diabetes. 2009 Jul;58(7):1526-31.

[36]. van Marken Lichtenbelt WD, Vanhommerig JW, Smulders NM, Drossaerts JMAFL, Kemerink GJ, Bouvy ND, et al. Cold-activated brown adipose tissue in healthy men. N Engl J Med. 2009 Apr 9;360(15):1500-8.

[37]. Cannon B, Nedergaard J. Brown adipose tissue: function and physiological significance. Physiol Rev. 2004 Jan;84(1):277-359.

[38]. Harms M, Seale P. Brown and beige fat: development, function and therapeutic potential. Nat Med. 2013 Oct;19(10):1252-63.

[39]. Mills EL, Pierce KA, Jedrychowski MP, Garrity R, Winther S, Vidoni S, et al. Accumulation of succinate controls activation of adipose tissue thermogenesis. Nature. 2018;560(7716):102-6.

[40]. Cousin B, Cinti S, Morroni M, Raimbault S, Ricquier D, Pénicaud L, et al. Occurrence of brown adipocytes in rat white adipose tissue: molecular and morphological characterization. J Cell Sci. 1992 Dec;103 ( Pt 4):931-42.

[41]. Guerra C, Koza RA, Yamashita H, Walsh K, Kozak LP. Emergence of brown adipocytes in white fat in mice is under genetic control. Effects on body weight and adiposity. J Clin Invest. 1998 Jul 15;102(2):412-20.

[42]. Zorena K, Jachimowicz-Duda O, Ślęzak D, Robakowska M, Mrugacz M. Adipokines and Obesity. Potential Link to Metabolic Disorders and Chronic Complications. Int J Mol Sci. 2020 May 18;21(10):3570.

[43]. Yanai H, Yoshida H. Beneficial Effects of Adiponectin on Glucose and Lipid Metabolism and Atherosclerotic Progression: Mechanisms and Perspectives. Int $\mathbf{J}$ Mol Sci. 2019 Mar 8;20(5):1190.

[44]. Polyzos SA, Kountouras J, Zavos C, Tsiaousi E. The role of adiponectin in the pathogenesis and treatment of non-alcoholic fatty liver disease. Diabetes Obes Metab. 2010 May;12(5):365-83.

[45]. Soty M, Penhoat A, Amigo-Correig M, Vinera J, Sardella A, Vullin-Bouilloux F, et al. A gut-brain neural circuit controlled by intestinal gluconeogenesis is crucial in metabolic health. Mol Metab. 2014 Dec 26;4(2):106-17. 
[46]. Baglioni S, Cantini G, Poli G, Francalanci M, Squecco R, Di Franco A, et al. Functional Differences in Visceral and Subcutaneous Fat Pads Originate from Differences in the Adipose Stem Cell. Gimble JM, editor. PLoS ONE. 2012 May 4;7(5):e36569.

[47]. Franczyk MP, He M, Yoshino J. Removal of Epididymal Visceral Adipose Tissue Prevents Obesity-Induced Multi-organ Insulin Resistance in Male Mice. J Endocr Soc. 2021 Feb 20;5(5):bvab024-bvab024.

[48]. Wu J, Cohen P, Spiegelman BM. Adaptive thermogenesis in adipocytes: Is beige the new brown? Genes Dev. 2013 Feb 1;27(3):234-50.

[49]. Cohen P, Levy JD, Zhang Y, Frontini A, Kolodin D, Svensson K, et al. Ablation of PRDM16 and Beige Adipose Causes Metabolic Dysfunction and a Subcutaneous to Visceral Fat Switch. Cell. 2014 Jan 16;156(0):304-16.

[50]. Seale P, Conroe HM, Estall J, Kajimura S, Frontini A, Ishibashi J, et al. Prdm16 determines the thermogenic program of subcutaneous white adipose tissue in mice. $\mathrm{J}$ Clin Invest. 2011 Jan;121(1):96-105. 


\section{FIGURE 1}

bioRxiv preprint doi: https://doi.org/10.1101/2021.10.25.465675; this version posted October 26, 2021. The copyright holder for this preprint (which was not certified by peer review) is the author/funder, who has granted bioRxiv a license to display the preprint in perpetuity. It is made $\mathbf{a}$ available under aCC-BY-NC-ND 4.0 International license.
-WT
口I.G6pc overexp

b

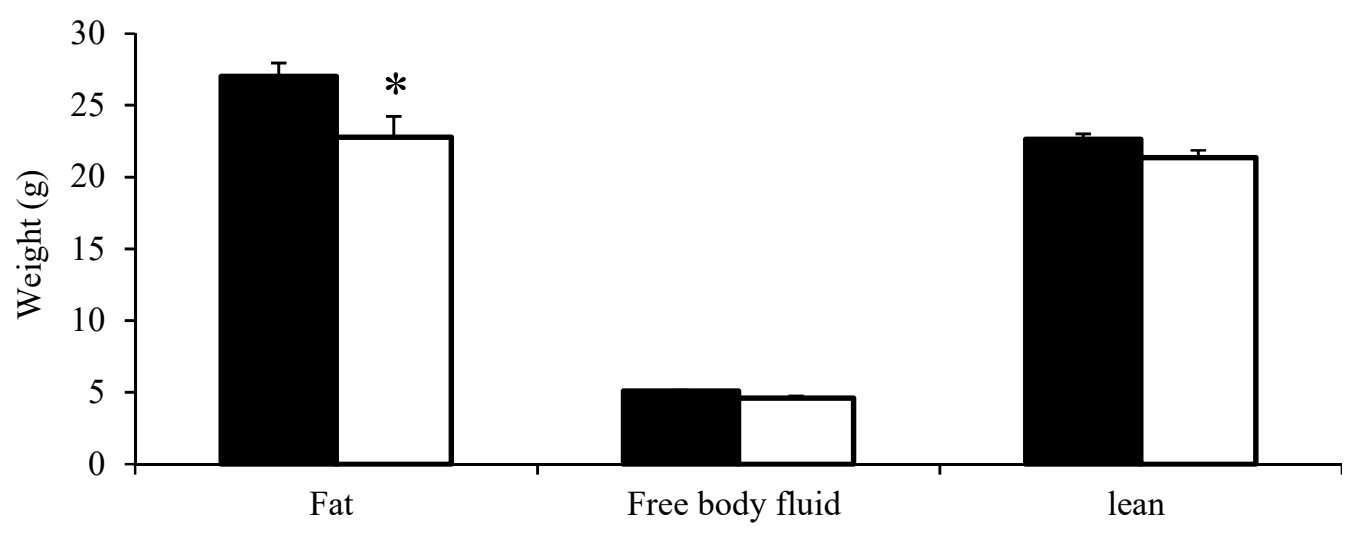

WT

I.G6pc overexp

eWAT
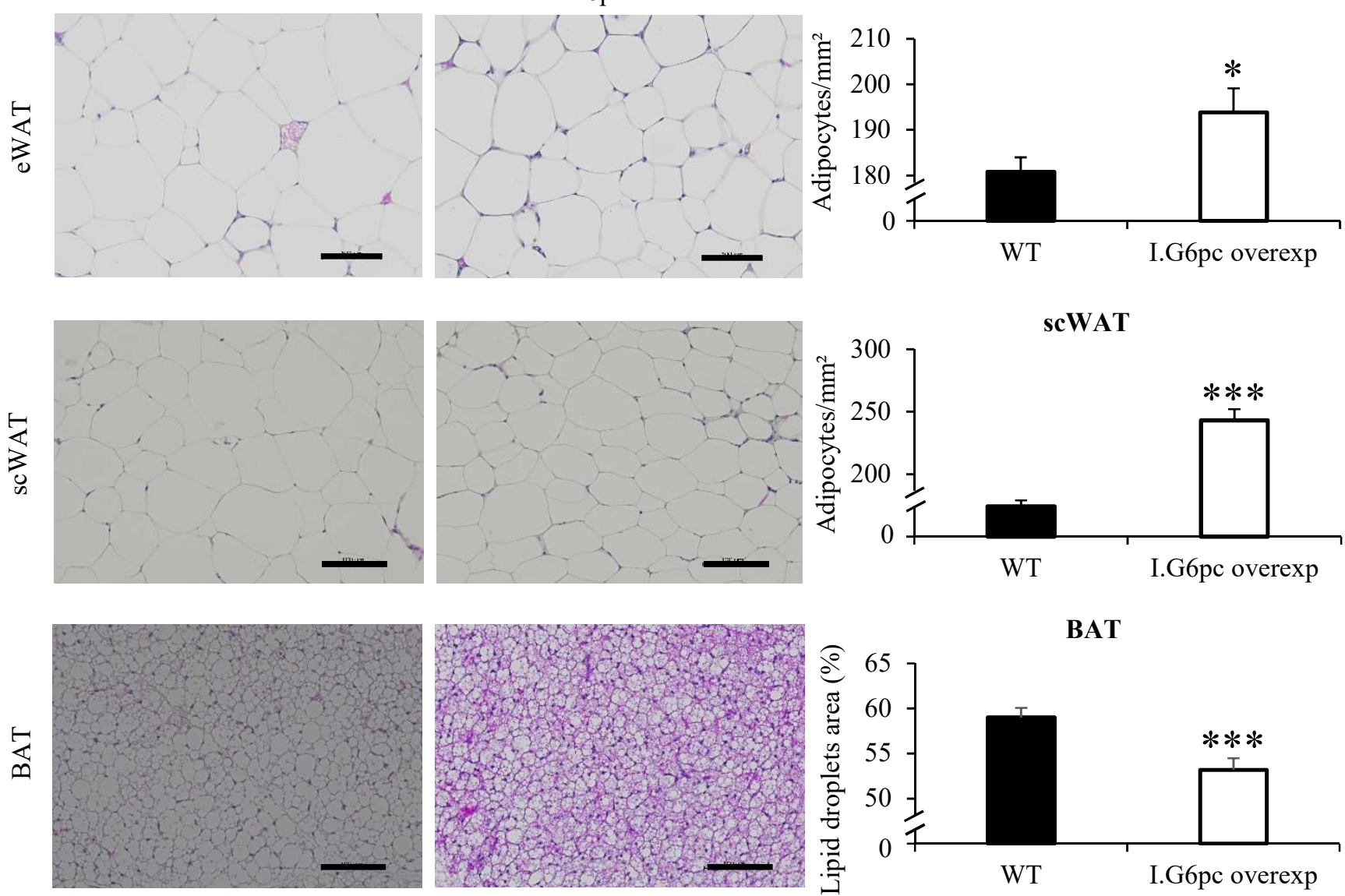

c

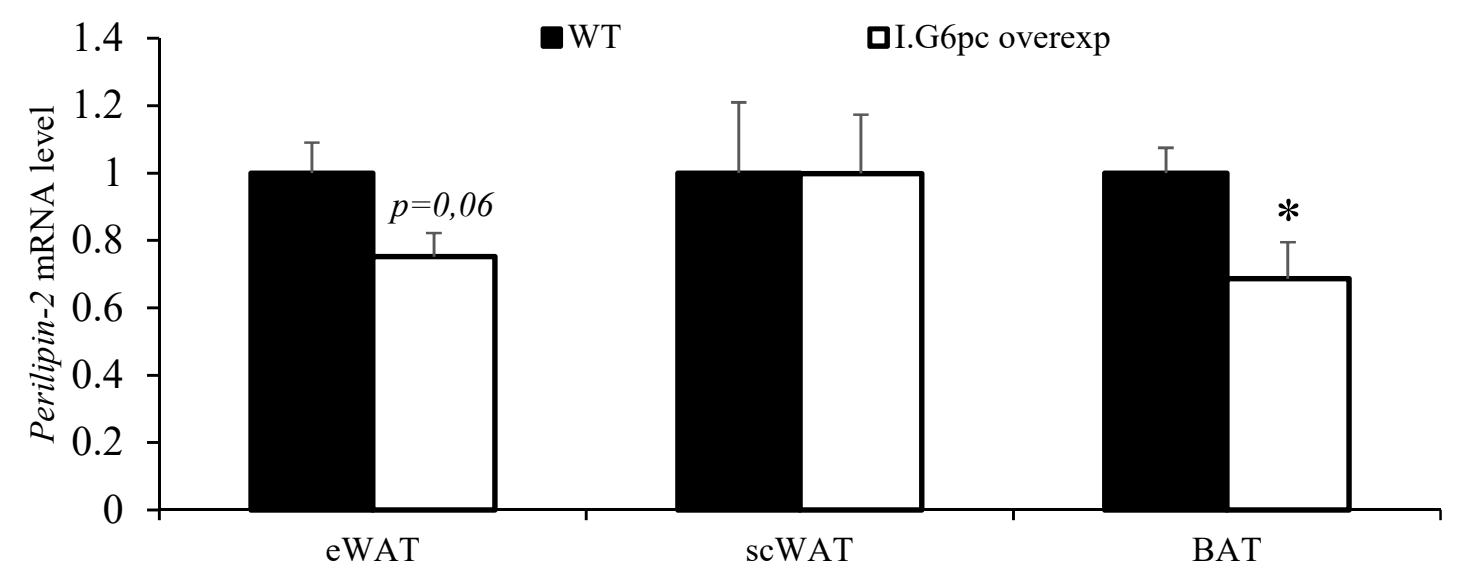




\section{FIGURE 2}

bioRxiv preprint doi: https://doi.org/10.1101/2021.10.25.465675; this version posted October 26, 2021. The copyright holder for this preprint (which was not certified by peer review) is the author/funder, who has granted bioRxiv a license to display the preprint in perpetuity. It is made available under aCC-BY-NC-ND 4.0 International license.

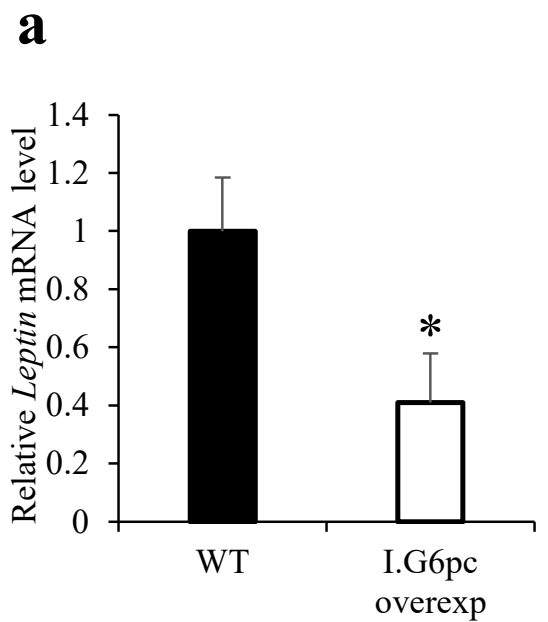

c

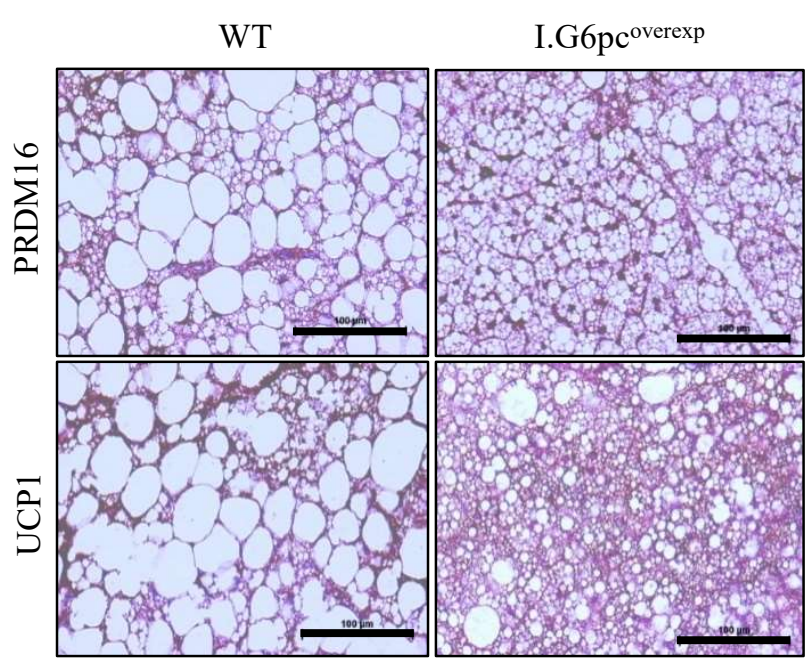

\section{b}
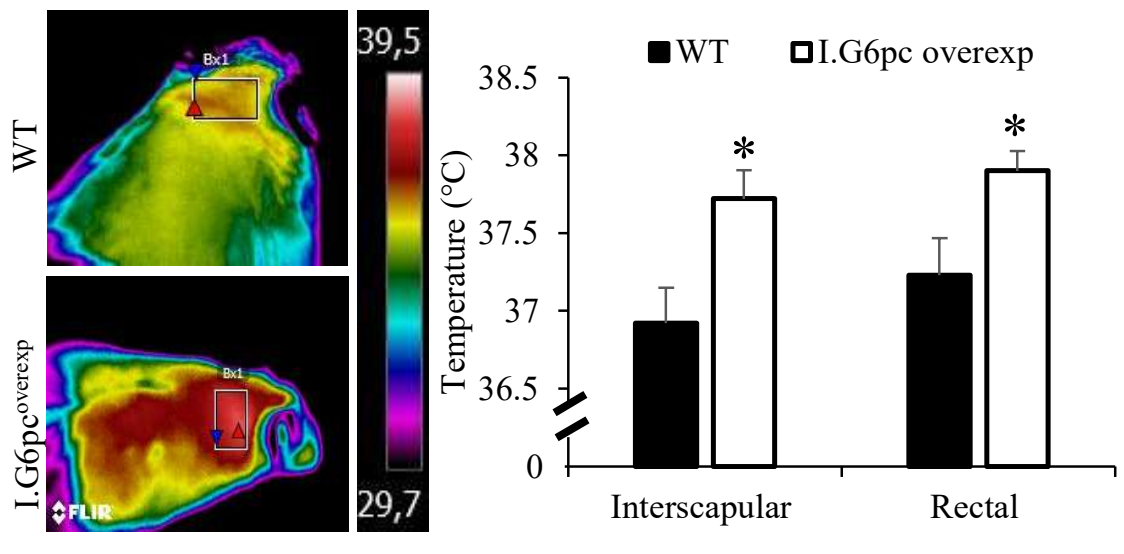

d

WT

I.G6pc $c^{\text {overexp }}$
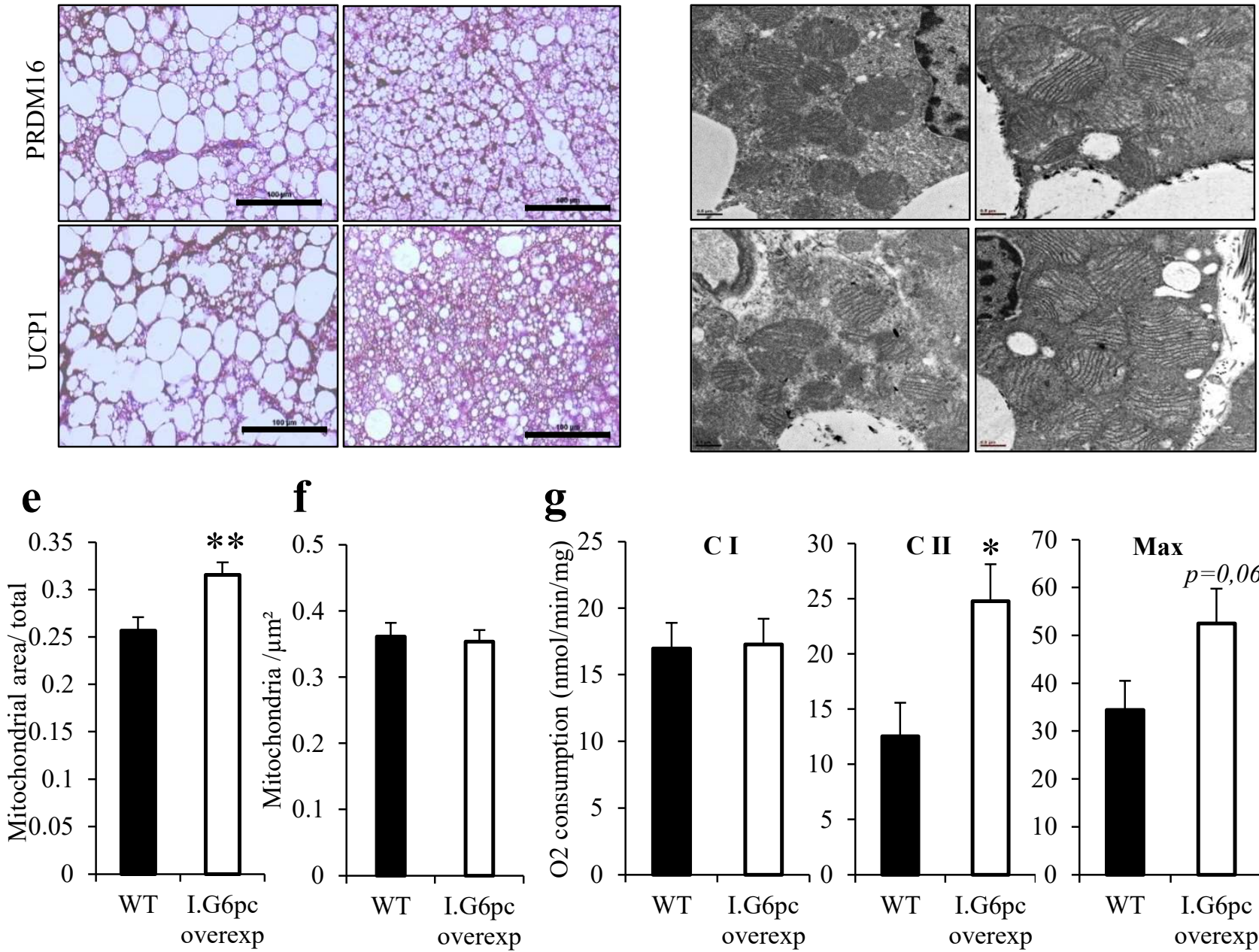

g

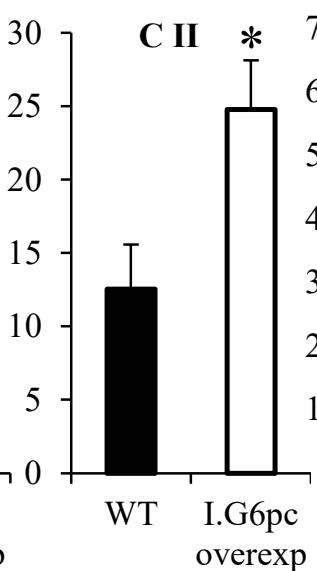

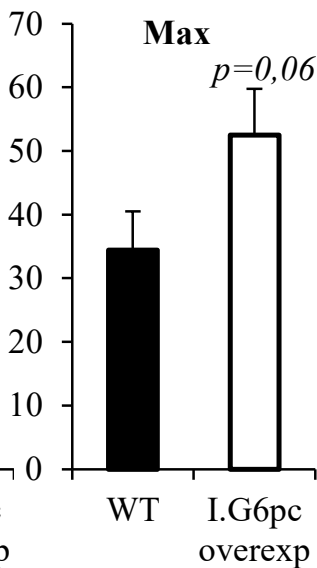




\section{FIGURE 3}

bioRxiv preprint doi: https://doi.org/10.1101/2021.10.25.465675; this version posted October 26, 2021. The copyright holder for this preprint (which was not certified by peer review) is the author/funder, who has granted bioRxiv a license to display the preprint in perpetuity. It is made available under aCC-BY-NC-ND 4.0 International license.

$\mathbf{a}$

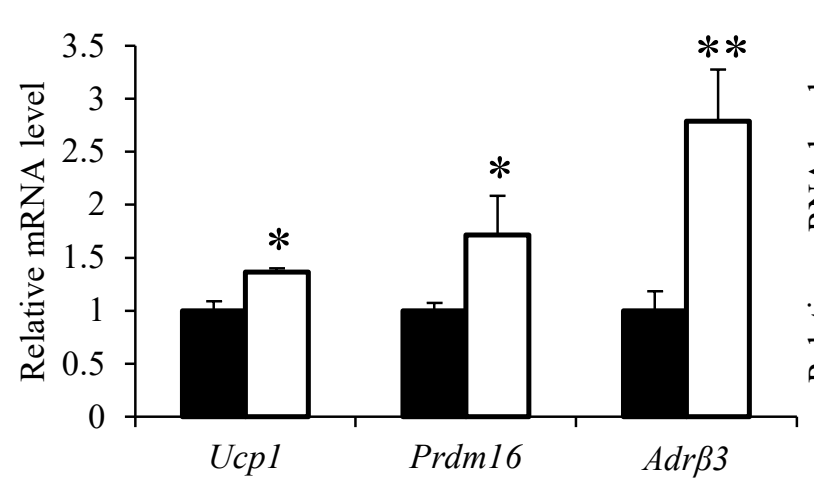

c
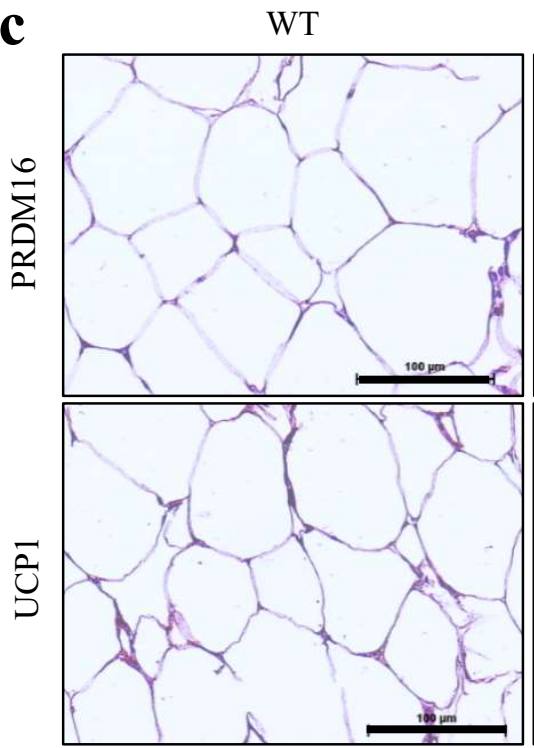

d

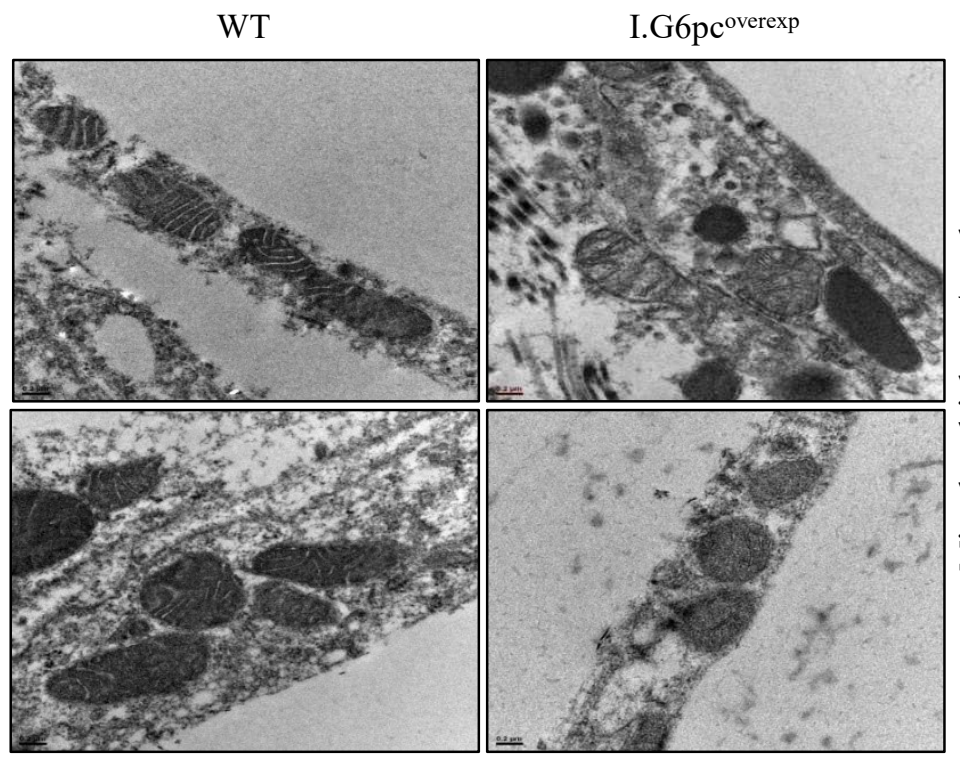

b

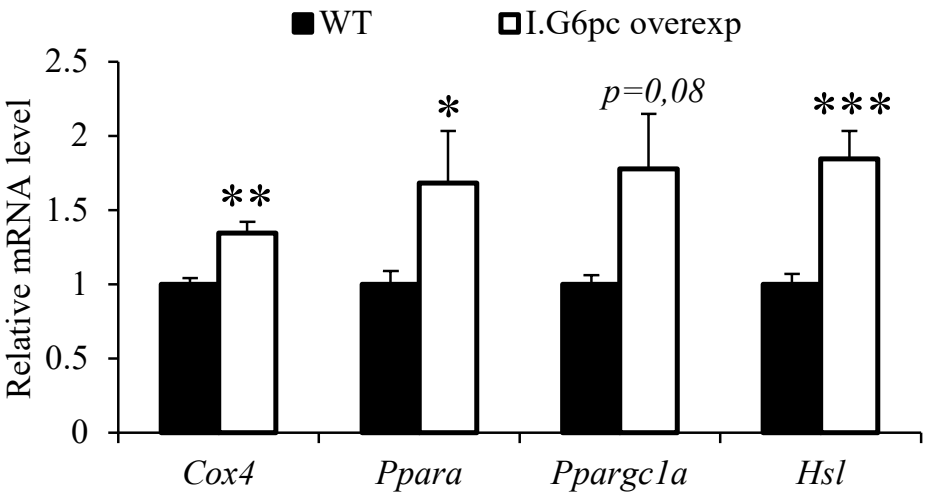

I.G6pc $\mathrm{c}^{\text {overexp }}$
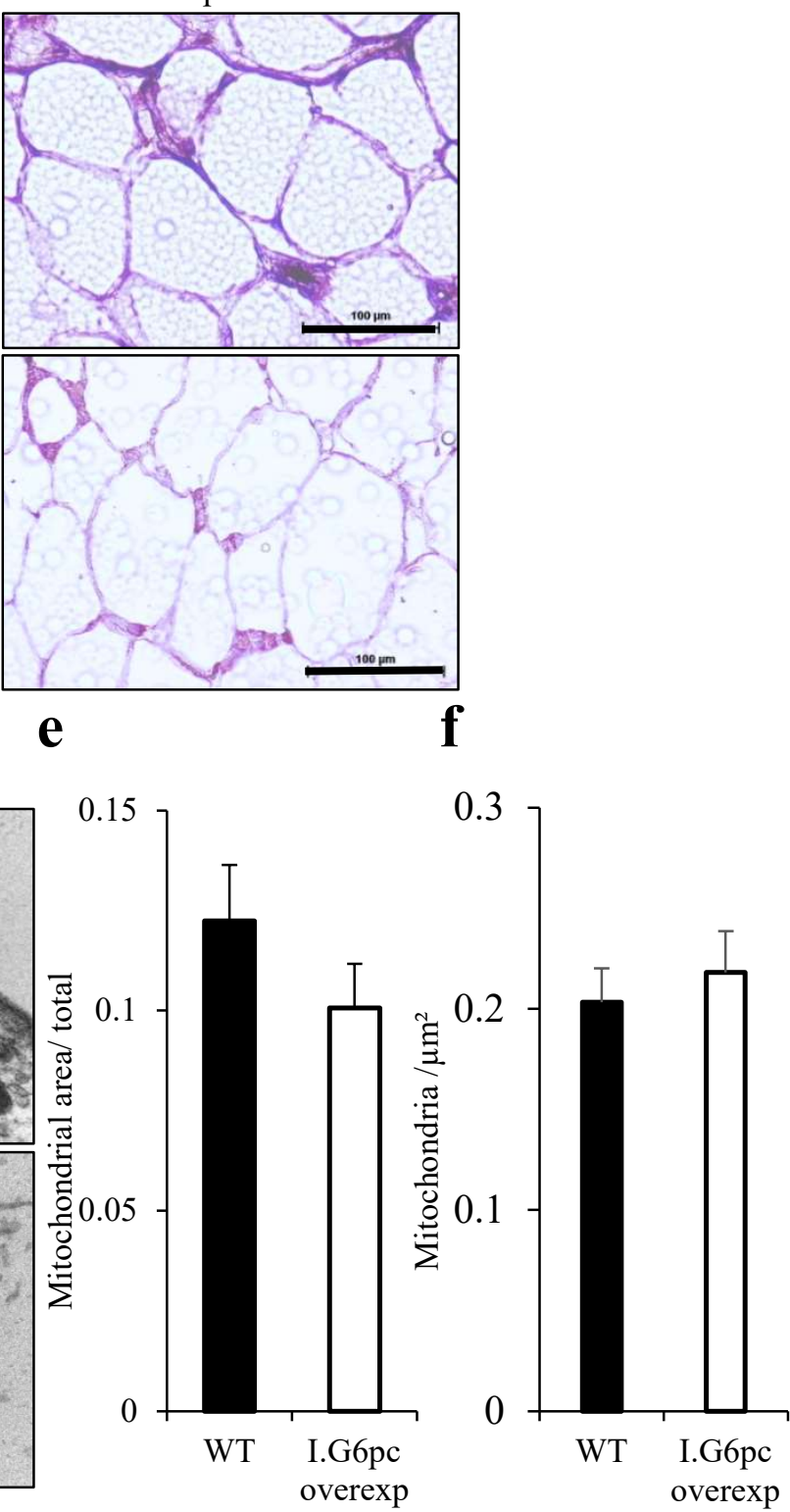


\section{FIGURE 4}

bioRxiv preprint doi: https://doi.org/10.1101/2021.10.25.465675; this version posted October 26, 2021. The copyright holder for this preprint (which was not certified by peer review) is the author/funder, who has granted bioRxiv a license to display the preprint in perpetuity. It is made available under aCC-BY-NC-ND 4.0 International license.
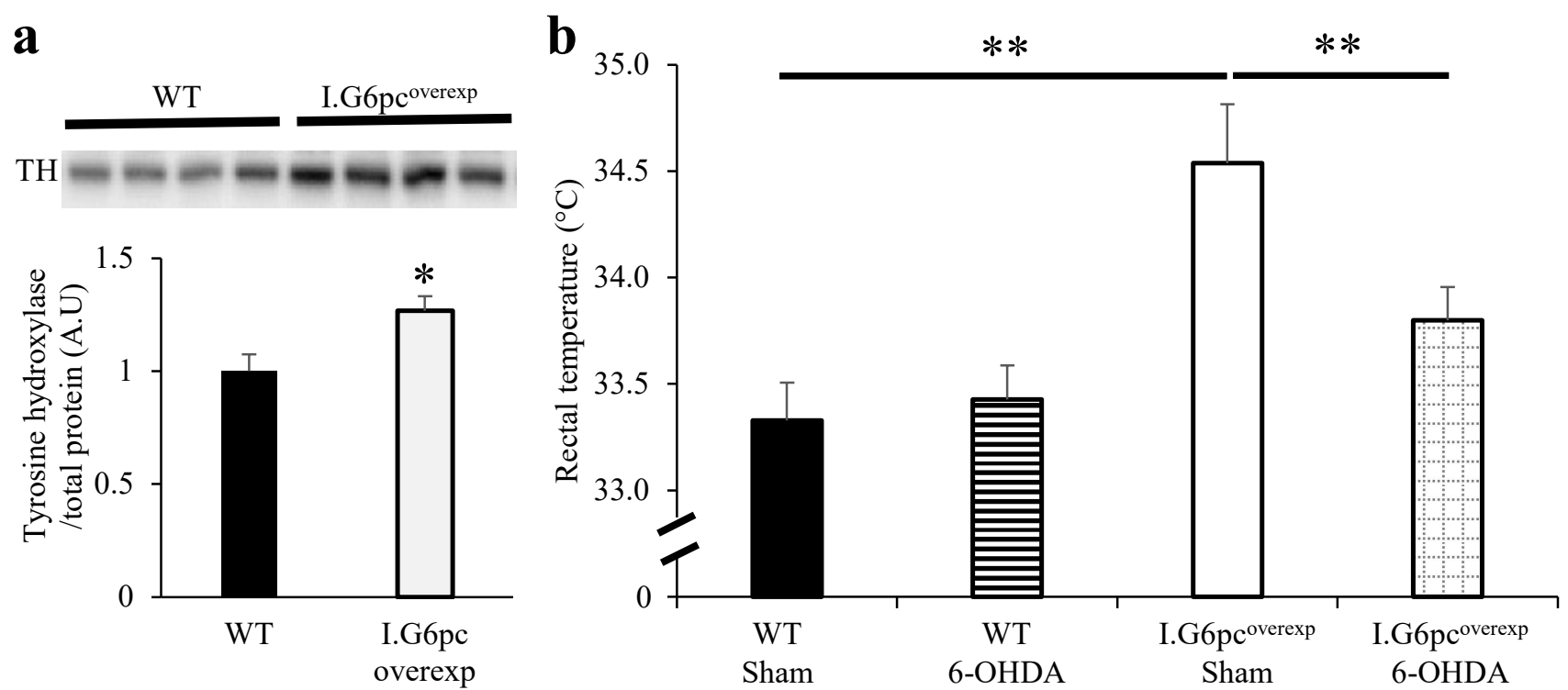


\section{FIGURE 5}

bioRxiv preprint doi: https://doi.org/10.1101/2021.10.25.465675; this version posted October 26, 2021. The copyright holder for this preprint (which was not certified by peer review) is the author/funder, who has granted bioRxiv a license to display the preprint in perpetuity. It is made available under aCC-BY-NC-ND 4.0 International license.

$\mathbf{a}$

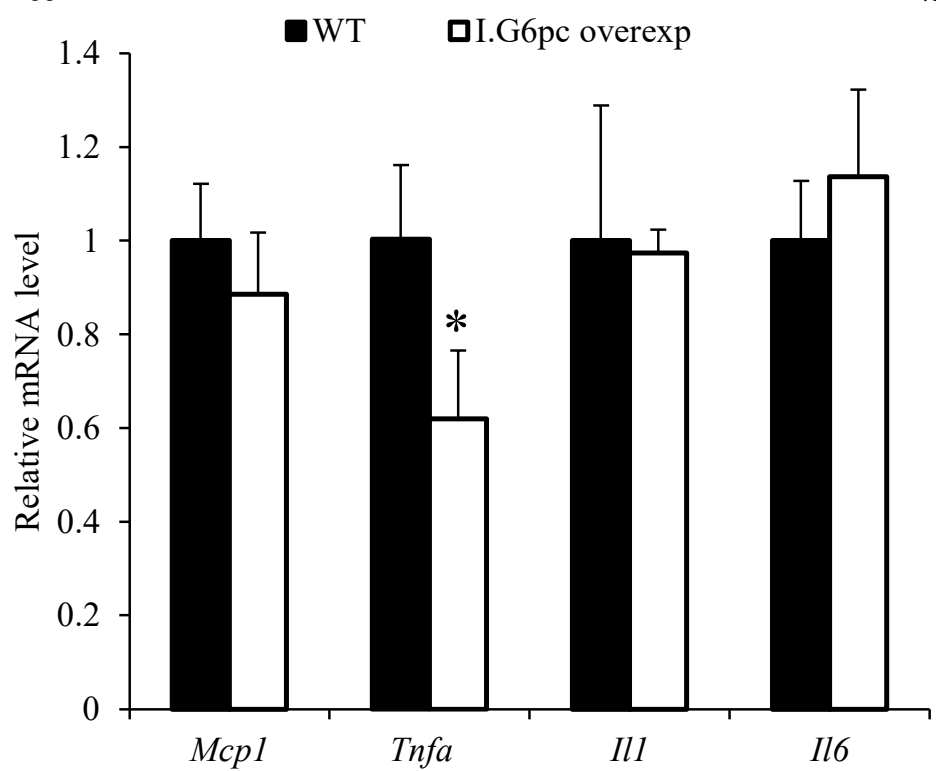

C

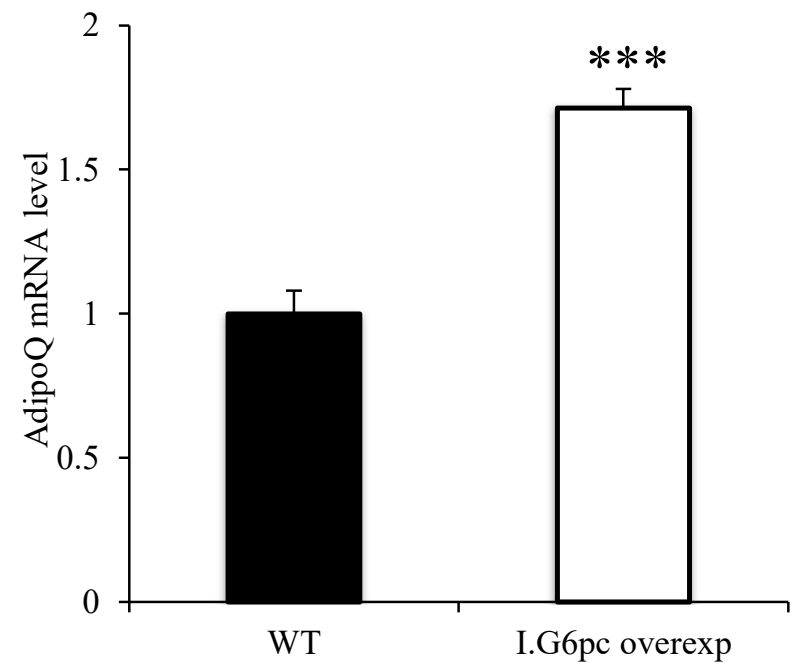

b
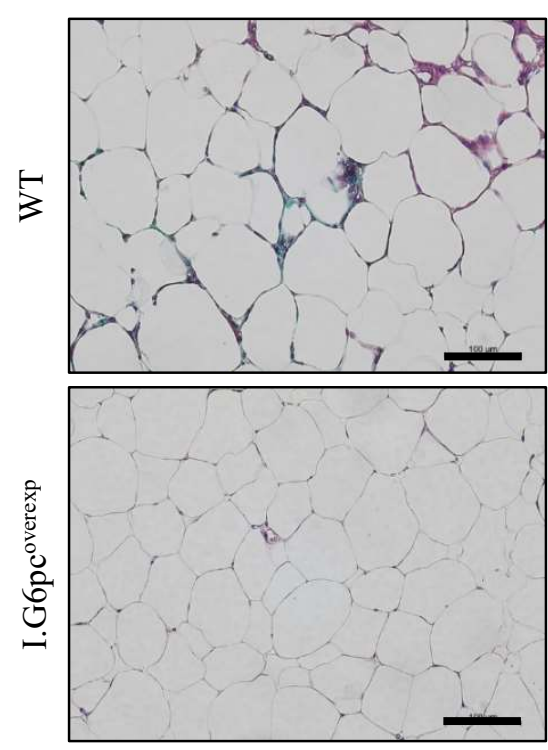

d

WT

I.G6pc $c^{\text {overexp }}$

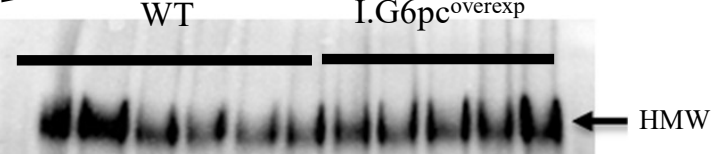

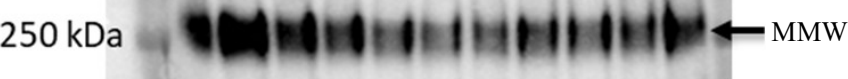

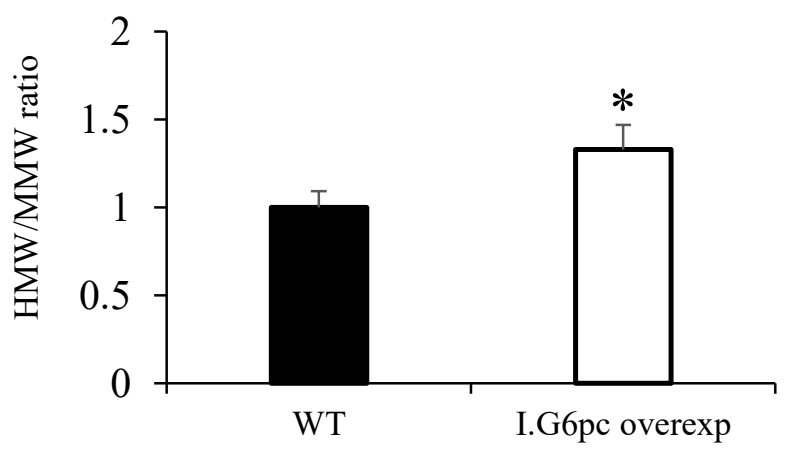




\section{FIGURE 6}

a bioRxiv preprint doi: https://doi.org/10.1/p1/2021.10.25.465675; this version ppsted October 26, 2021. The copyright holder for this preprint (which was not certified by peer review) 1 the author/funder, who has granted broRxiv a license to display the preprint in perpetuity. It is made

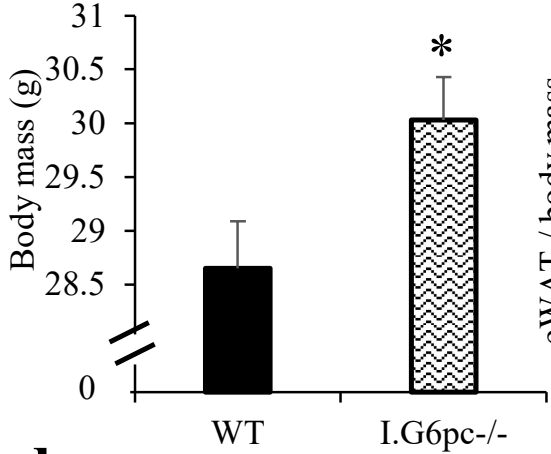

d
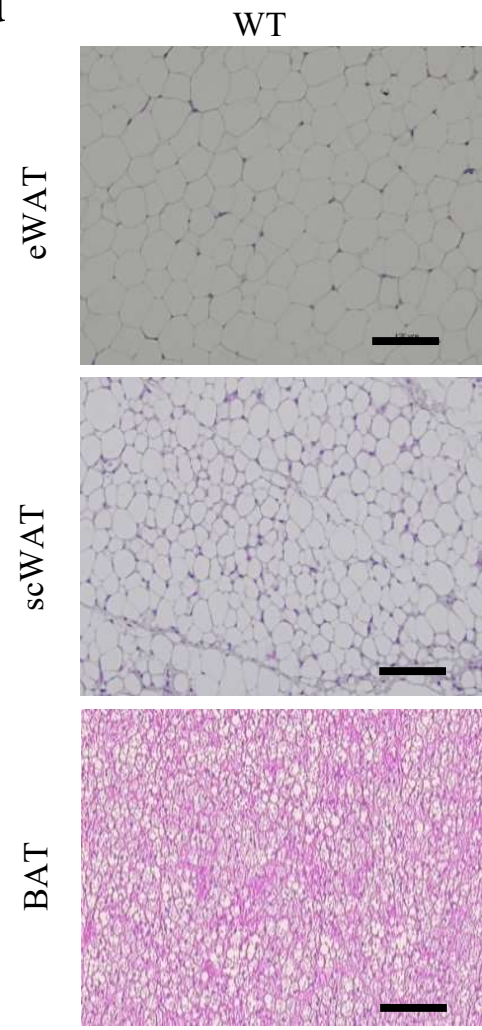

e

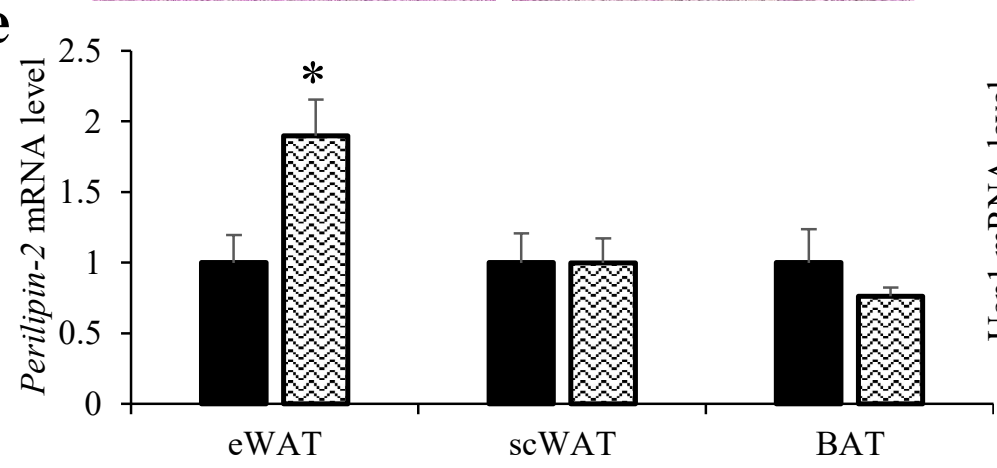

g

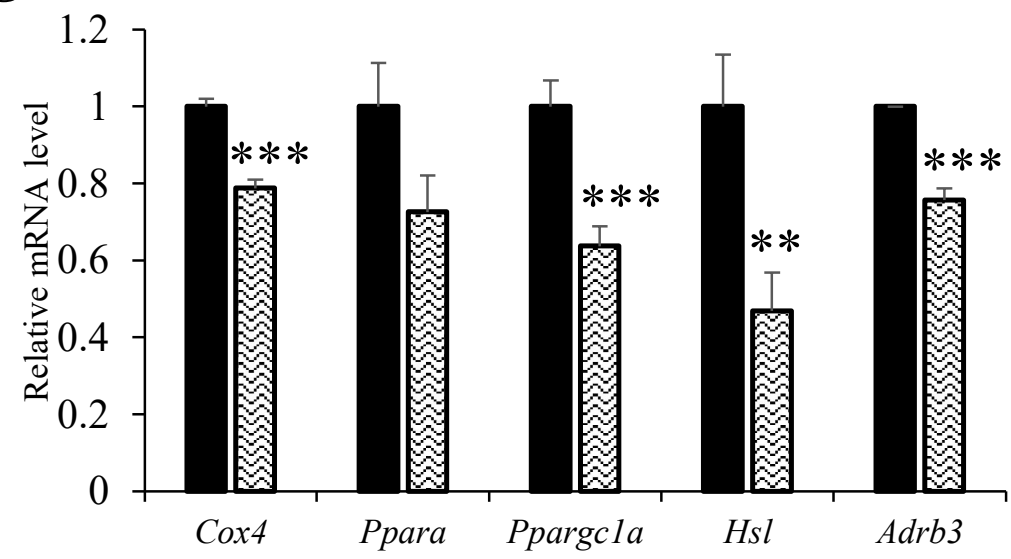

I.G6pc-/-

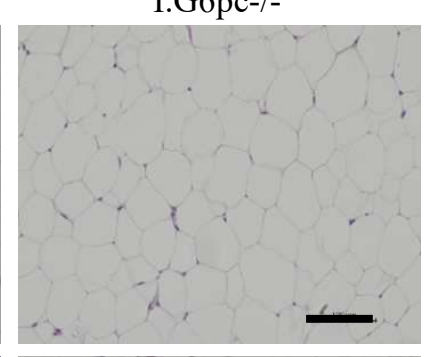

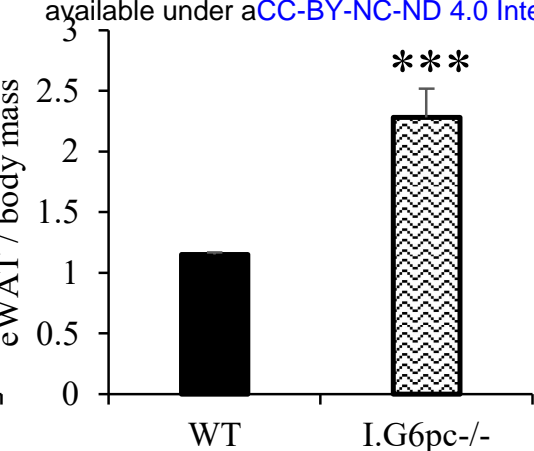
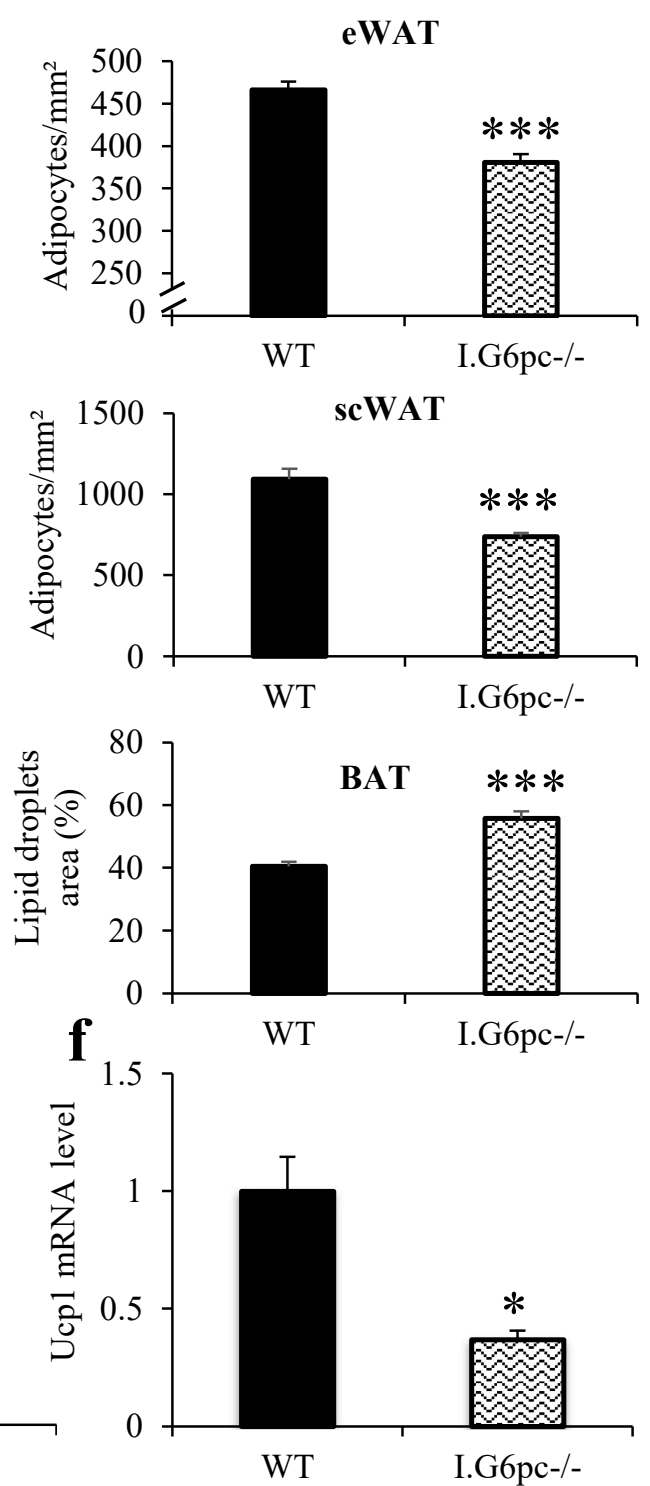

h
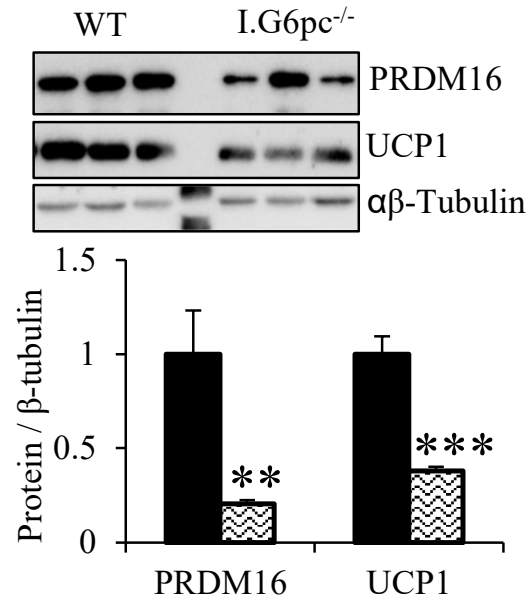


\section{FIGURE 7}

bioRxiv preprint doi: https://doi.org/10.1101/2021.10.25.465675; this version posted October 26, 2021. The copyright holder for this preprint (which was not certified by peer review) is the author/funder, who has granted bioRxiv a license to display the preprint in perpetuity. It is made available under aCC-BY-NC-ND 4.0 International license.

a

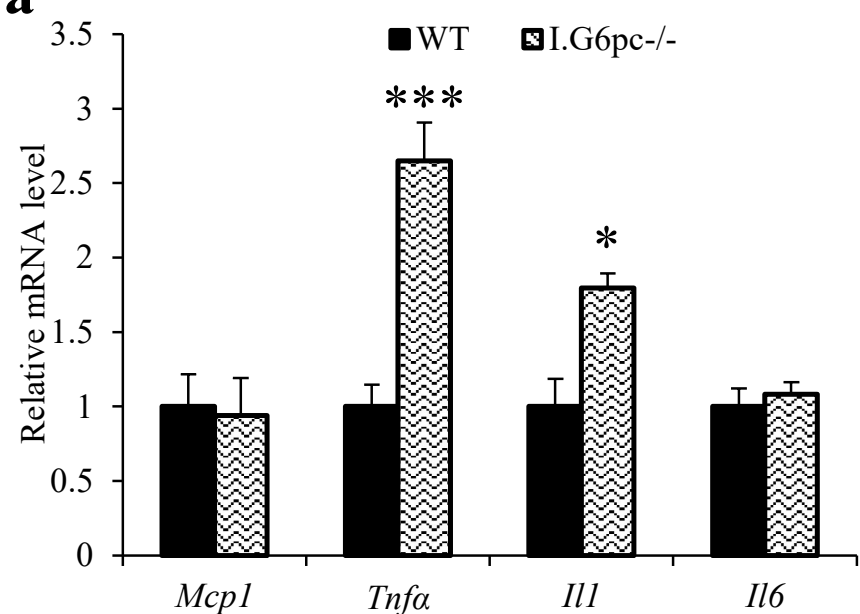

c

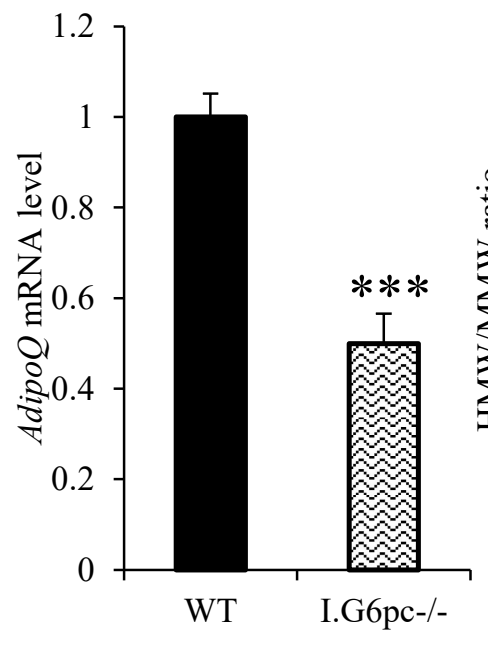

d

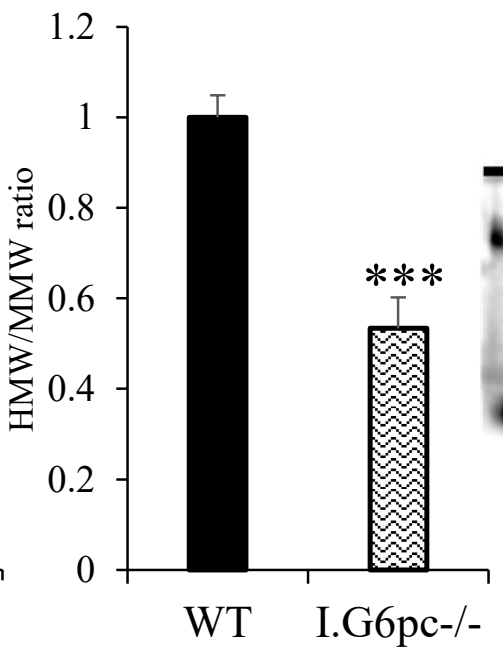

b
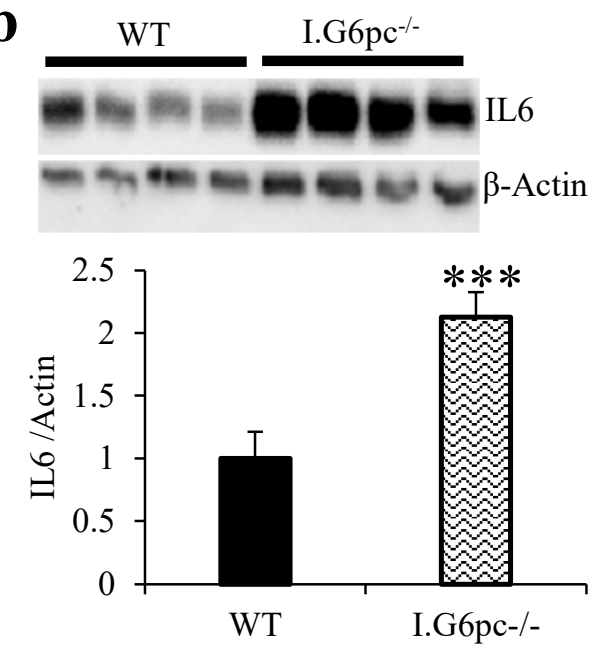

WT I.G6pc $\mathrm{p}^{-/}$

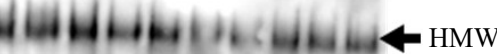

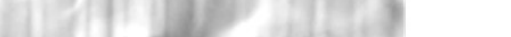


bioRxiv preprint doi: httbst//abi.org/10.1101/2021.10.25.465675; this version posted October 26, 2021. The copyright holder for this preprint (which was not certified by peer review) is the author/funder, who has granted bioRxiv a license to display the preprint in perpetuity. It is made

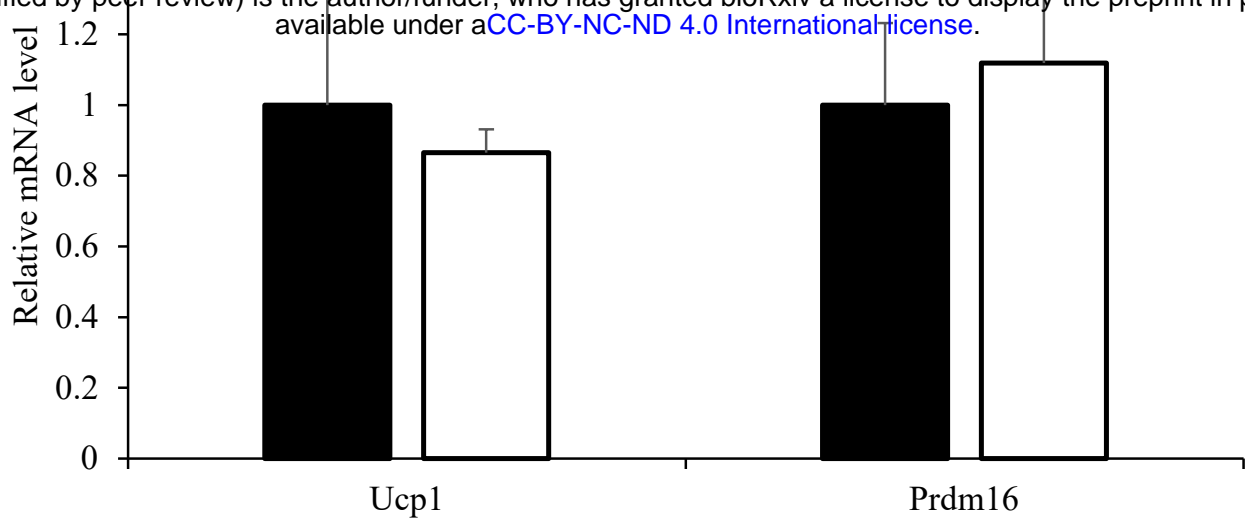

Supplemental figure 1: RNAm expression level of thermogenesis markers in subcutaneous white adipose tissue of I.G6pcoverexp and WT mice. Student's t-test was performed as a statistical analysis (means \pm SEM, $n=4-6$ ).

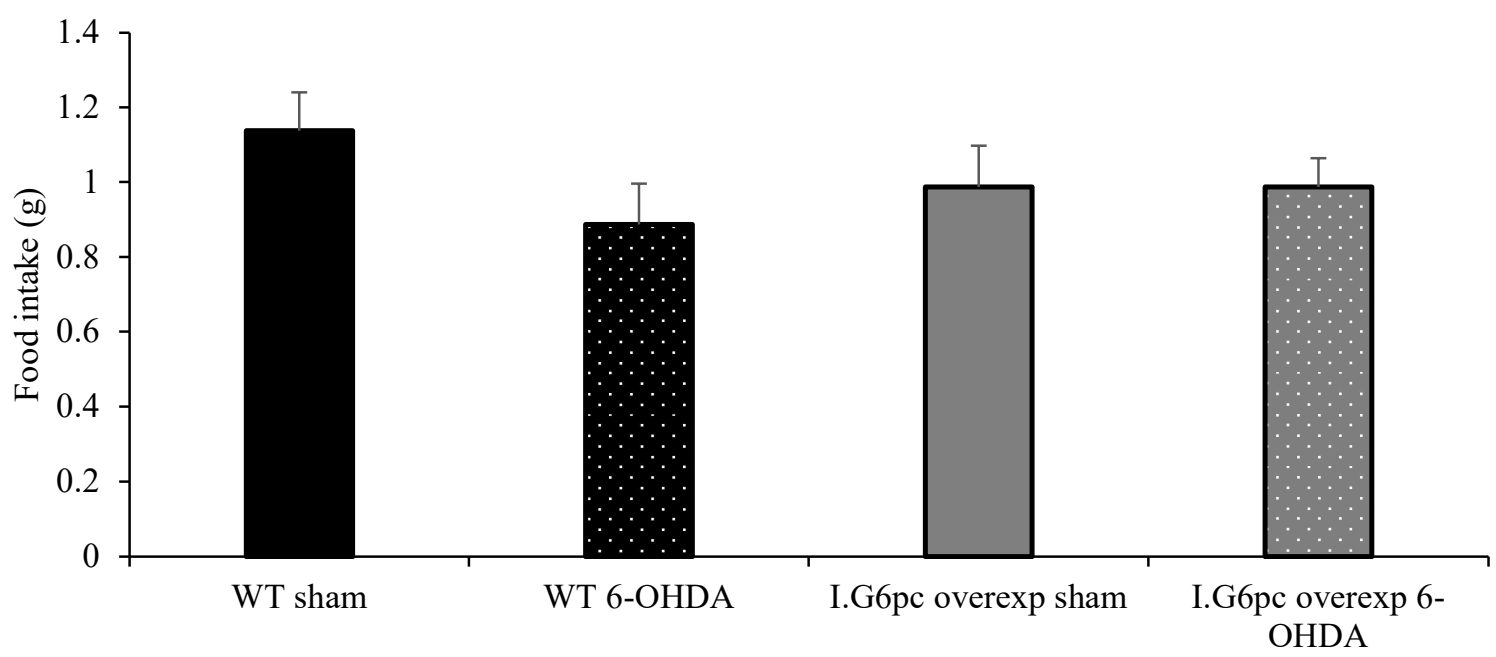

Supplemental figure 2: Effects of denervation of the sympathetic system innervating brown adipose tissue on food intake of WT and I.G6pcoverexp mice during 4 hours of cold exposure. (means \pm SEM, $n=6-7$ ). Student's t-test was performed as a statistical analysis. 


\section{Figure 1: Induction of intestinal gluconeogenesis decreases fat mass expansion induced}

\section{by high fat-high sucrose diet}

(a) Body composition of I.G6pc ${ }^{\text {overexp }}$ and WT mice (means \pm SEM, n= 6-7) (b) Representative hematoxylin and eosin staining of eWAT, scWAT and BAT histological sections and quantification (Numbers of adipocytes per $\mathrm{mm}^{2}$ for WAT and the lipid droplets area for BAT) (means \pm SEM, $n=6$; 4-15 pictures per mice). Scale bar represents $100 \mu \mathrm{m}$. (c) Relative mRNA levels of Perilipin in the eWAT, scWAT and BAT (means \pm SEM, $n=5$ ). (a-c) Student's t-test was performed as a statistical analysis. $* \mathrm{p}<0.05$ versus WT mice.

\section{Figure 2: Induction of intestinal gluconeogenesis prevents brown adipose tissue}

\section{whitening induced by high fat-high sucrose diet}

(a) Relative mRNA levels of Leptin in the BAT (means \pm SEM, $n=5-6$ ) (b) Skin temperature surrounding the BAT (interscapular region) and rectal temperature (means \pm SEM, $n=6-7$ ) (c) Representative pictures of UCP1 and PRDM16 staining (in brown) of BAT histological sections. Scale bar represents $100 \mu \mathrm{m}$. (d-e-f) Representative pictures of electronic microscopy of BAT sections, scale bar represents $0.5 \mu \mathrm{m}$ (d) and quantification of mitochondria area (e) and number per $\mu \mathrm{m}^{2}$ (f) $(\mathrm{n}=4 ; 10$ pictures per mice). (g) Measure of BAT mitochondria respiratory capacity (means \pm SEM, $n=12-13$ ). (a-f) Student's t-test was performed as a statistical analysis. ${ }^{*} \mathrm{p}<0.05 ; * * \mathrm{p}<0.01$ versus WT mice.

\section{Figure 3: Induction of intestinal gluconeogenesis promotes the browning of epididymal} $\underline{\text { white adipose tissue in mice fed high fat-high sucrose diet }}$

(a) Relative mRNA levels of genes implicated in thermogenesis capacity (means \pm SEM, n=4-

6). (b) Relative mRNA levels of genes involved in WAT lipolysis (means \pm SEM, $n=4-6$ ). (c) Representative pictures of UCP1 and PRDM16 staining (in brown) of eWAT histological 
sections. Scale bar represents $100 \mu \mathrm{m}$. (d-e-f) Representative pictures of electron microscopy of eWAT sections, Scale bar represents $0.5 \mu \mathrm{m}(\mathrm{d})$ and quantification of mitochondria area (e) and number per $\mu m^{2}$ (f) $(n=4 ; 10$ pictures per mice). Student's t-test was performed as a statistical analysis. $* \mathrm{p}<0.05 ; * * \mathrm{p}<0.01 ; * * \mathrm{p} p<0.001$ versus WT mice.

Figure 4: Induction of intestinal gluconeogenesis potentiates the resistance to cold and increases energy expenditure in mice fed high fat-high sucrose diet

(a) Relative quantification of tyrosine hydroxylase protein levels in the eWAT (means \pm SEM, $\mathrm{n}=4-6$ ) and representative western blot picture. (b) Rectal temperature of mice after sympathetic denervation restricted to the BAT (6-OHDA-treated vs Sham) following 4-hours cold exposure $\left(6^{\circ} \mathrm{C}\right)$ (means \pm SEM, $\left.n=7-8\right)$. (a-b) Student's t-test (A) or ANOVA-2 followed by Bonferroni post-hoc test (B) was performed as a statistical analysis. ${ }^{*} \mathrm{p}<0.05 ; * * \mathrm{p}<0.01$ versus WT mice.

Figure 5: Induction of intestinal gluconeogenesis protects against deleterious changes in adipokine secretion profile induced by high fat-high sucrose diet

(a) Relative mRNA levels of genes involved in pro-inflammatory processes (means $\pm \mathrm{SEM}$, $\mathrm{n}=5-6$ ). (b) Masson trichrome staining of liver histological sections. Scale bar represents 100 $\mu \mathrm{m}$. (c) mRNA levels of Adipo $Q$ expression (means \pm SEM, $n=4-6$ ). (d) Representative image of non-denaturing SDS-PAGE in the eWAT. The graph shows the quantification of High Molecular Weight (HMW)/Medium Molecular Weight (MMW) forms (means \pm SEM, n= 1012). (a-d) Student's t-test was performed as a statistical analysis. $* \mathrm{p}<0.05$; $* * * \mathrm{p}<0.001$ versus WT mice.

Figure 6: Absence of intestinal gluconeogenesis promotes adipose tissue alterations (in $\underline{\text { standard diet) }}$ 
(a) Body mass of I.G6pc ${ }^{-/-}$and WT mice (means \pm SEM, n=7-8). (b-c) eWAT and scWAT mass relative to body mass (means \pm SEM, $n=7-8$ ). (d) Representative hematoxylin and eosin staining of eWAT, scWAT and BAT histological sections and quantification (Numbers of adipocytes per $\mathrm{mm}^{2}$ for WAT and the lipid droplets area for BAT) (means \pm SEM, $\mathrm{n}=6$; 4-15 pictures per mice). Scale bar represents $100 \mu \mathrm{m}$. (e) Relative Perilipin mRNA expression levels in the eWAT, scWAT and BAT (means \pm SEM, $n=4-6$ ). (f) Relative mRNA levels of Ucpl in the BAT (means \pm SEM, $\mathrm{n}=3-4)$. (g) Relative mRNA levels of genes involved in eWAT lipolysis and lipid oxidation (means \pm SEM, $n=4-6$ ). (h) Relative quantification of protein levels of PRDM16 and UCP1 in the eWAT (means \pm SEM, $n=5$ ) and representative western blot picture. (a-h) Student's t-test was performed as a statistical analysis. ${ }^{*} \mathrm{p}<0.05$; $* * * \mathrm{p}<0.001$ versus WT mice.

\section{Figure 7: Absence of intestinal gluconeogenesis promotes deleterious changes in}

\section{$\underline{\text { adipokine secretion profile (in standard diet) }}$}

(a) Relative mRNA levels of genes involved in pro-inflammatory processes (means \pm SEM, $n=5-6$ ). (b) Relative quantification of protein levels of IL6 in the eWAT (means \pm SEM, $n=5$ ) and representative western blot picture. (c) Relative mRNA levels of Adipo $Q$ expression (means \pm SEM, $n=7$ ). (d) Representative image of non-denaturing SDS-PAGE in the eWAT. The graph shows the quantification of MHW/MMW forms (means \pm SEM, $n=5$ ). (a-d) Student's t-test was performed as a statistical analysis. ${ }^{*} \mathrm{p}<0.05 ; * * * p<0.001$ versus WT mice. 
bioRxiv preprint doi: https://doi.org/10.1101/2021.10.25.465675; this version posted October 26, 2021. The copyright holder for this preprint (which was not certified by peer review) is the author/funder, who has granted bioRxiv a license to display the preprint in perpetuity. It is made available under aCC-BY-NC-ND 4.0 International license. 